Review

\title{
Potential of Baltic region peat in high added-value products and environmentally friendly applications - a Revew
}

\author{
Janis Krumins ${ }^{1}$, Maris Klavins' ${ }^{1}$, Anastasija Tumilovich ${ }^{2}$, Kristine Irtiseva ${ }^{2}$, Viktors Mironovs ${ }^{3}$, Vjacesavs Lapkov-

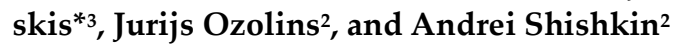

1 Department of Environmental Science, University of Latvia, Raiṇa bulv. 19, Rīga, LV 1586, Latvia; J.K. janis.krumins@lu.lv, M.K. maris.klavins@lu.lv

2 Rudolfs Cimdins Riga Biomaterials Innovations and Development Centre of RTU, Institute of General Chemical Engineering, Faculty of Materials Science and Applied Chemistry, Riga Technical University, Pulka 3, K-3, Riga, LV-1007, Latvia. A.T. anastasija.tumilovica@rtu.lv, K.I. kristine.irtiseva@rtu.lv, J.O. jurijs.ozolins@rtu.lv, A.S. andrejs.siskins@rtu.lv

3 Scientific Laboratory of Powder Materials \& Institute of Aeronautics, 6B Kipsalas Str., Faculty of Mechanical Engineering, Riga Technical University, Riga LV-1048, Latvia. V.M. viktors.mironovs@rtu.lv, V.L. vjaceslavs.lapkovskis@rtu.lv

* Correspondence: vjaceslavs.lapkovskis@rtu.lv

\begin{abstract}
Present review is dedicated to use of peat on example of fen peat in high added-value products and applications. Mainly, but not limited, last decade literature was analysed from perspective of innovation potential of peat applications in environmental technologies on examples of studies from the Baltic Sea region. Paper covers a wide range of applications of peat products started from agriculture to medicine and cosmetics. A separate chapter is devoted to the deep-processed peat product - humic substances (humate, humic and fulvic salts and acids). Generalised dependence of product extraction rate and its properties, depending on the process parameters are provided. Widely are described applications of the humic substance applications covering economic aspects, such as production costs. In the last chapter of the review are given recommendations for applications considering most recent trends of peat-based product developments. This accumulated information could be useful for future production, development of new, environmentally friendly products and start-ups establishment.
\end{abstract}

Keywords: peat; peat-based product; peat treatment; added-value products; environmentally friendly; homogeisation, pyrolysis; fulvic acid; humic acid; humic substances;

\section{Introduction}

Although it is evident that peat excavation, either it is raised bog or fen peat, will always generate certain amount of greenhouse gas emissions; however, it is not highlighted enough that wise and reasonable use of peat resources can compensate these emissions and even contribute to climate change mitigation. A lack of mindfulness of the full aids that mires can offer has resulted in a severe overutilization and degradation of these ecosystems worldwide. The overexploitation and degradation mainly are done through the drainage, agricultural conversion, burning or peat excavation for fuel. While raised bogs generally are used for peat commercial excavation, fens, for the most part, are affected by drainage and following agricultural conversion, that have had resulted in a major ecosystem degradation and a significant increase in greenhouse gas emissions from these territories. In many occasions raised bogs contain fen peat layers of great thickness, which however are not being excavated after the valued raised bog peat layer is removed. These fen peat layers are left to mineralize until mire recultivation, which again significantly adds to the greenhouse gas emissions as stored gases are released in the atmosphere. Thus, new products and applications for fen peat that is otherwise left after raised bog peat removal can be not only cost-effective, but also are vital to climate change reduction and environmental sustainability in general. For example, using fen peat as a growing 
medium or a supplement for growing mediums, or in other environmental products and applications of that matter can capture these generated greenhouse gas emissions back in the soil and hence making use of peat close to climate neutral. So, the balance between peat excavation and wise use can lead to mitigation of climate change, while also providing with worthful economic benefits.

In 2020 about $95 \%$ of excavated peat in Latvia is used in horticulture, yet it is raised bog peat. A broad use of peat substrates in horticulture can help offset greenhouse gas emissions, because plants that are grown in peat substrates can virtually compensate the emissions caused by raised bog peat excavation. At the same time, fen peat is frequently unused and afterwards raised bog peat layer removal its mineralization commences, which is followed by greenhouse gas emissions. Thus, it is essential to either find applications for this resource or swift ways for recultivation of peat excavation sites, to prevent further expanse of greenhouse gas emissions from fen peat.

Fens are major sinks for atmospheric carbon and figure prominently in just about all scenarios of carbon dioxide induced global change, consequently their preservation is crucial for environmental sustainability and reducing the acceleration of presently going on climate change effects [1]. The general aim of this review is to suggest new product and application options for fen peat that is otherwise left in mires after raised bog peat excavation is complete.

Mire management in European Union has to follow guidelines of the European Commission and programs, which are put into practice in the field of environment, agriculture and infrastructure [2]. The management of mire resources is regulated by the European Union environmental law; environmental damage law; the structural, regional and rural development policies; climate legislation; nature conservation legislation and many other guiding principles, all of which are on purpose for steadily reducing the extent for peat extraction and use in the European Union, in regards to reduce greenhouse gas emissions and climate change [3]-[6] as the generally accepted and applied wholesome mire management practices in the European Union are still requiring [7]. Therefore, it can be concluded that most of existing European Union policies regarding mires and peat, and their management are more based on populist views and refer to a range of political standpoints that emphasize the idea of general public, while they are not entirely based on indepth and comprehensive research and evidence. Thus, their re-evaluation, in-depth assessment, including the conformity evaluation are strongly advised.

The authors approve that climate change presents perhaps the most profound challenge ever to have confronted social, political, and economic systems of the world. The industry, chiefly use of fossil fuels, causes major release of heat-trapping gases into the atmosphere. This, coupled with the expansion of agricultural activities and damage to natural ecosystems, is causing the average temperature of the world to increase. For instance, a number of studies in climate research show that drained fens that are then often used for agriculture, while covering only roughly half a percent of the world's terrain, emit more than $5 \%$ of global carbon dioxide emissions [8]. In addition, up to $60 \%$ of all human initiated greenhouse gas emissions from 2005 to 2015 were just by reason of various land use emissions and it is still going on. At the same time, the introduction of various policies, guidelines and constraints has led to a notable reduction of greenhouse gases in post-soviet countries. For example, before the collapse of the Soviet Union in 1991, greenhouse gas emissions from croplands in the Baltic States were much higher than nowadays [9].

The authors suggest that the limitation of peat excavation and mire management both have to be based on some criteria, which is set by a limit, such as the greenhouse gas emission factor, but up to this set limit the extraction should be tolerable and all the more so if use of peat can facilitate the return of the emissions back to the ground and assist climate neutrality. One of good examples for such facilitation is use of peat substrates for agricultural and horticultural functions. If peat is used as a substrate for crops, then plants 
in this nutrient-rich substrate are actively using photosynthesis to absorb carbon dioxide from the atmosphere to produce more green mass. Moreover, plants also offset the loss of carbon dioxide through respiration. This example alone lets us conclude that wise and reasonable use of peat resources can make up for carbon dioxide emissions that are released as the result from peat excavation and even facilitate the return of some of the emissions caused by other industries back to the ground.

The general aim of this review is to recapitulate use of fen peat and its components in high added-value products and applications, and to postulate the information of a recommendatory nature for fen peat use. The attention here is made on fen peat as this resource in comparison to raised bog peat in Latvia is practically unexploited on an economically sufficient amount and has practically no industrial value due to substantial differences between peat types, their composition and vanity as fuel. In this review authors are advising wide range of sectors and application possibilities, where fen peat can be used as a foundation or as one with raised bog peat. Correspondingly, promising uses of certain fen peat components, such as humic acids are thoroughly described. The authors are promoting environmentally friendly peat-based products and where reversing or stopping environmental damage caused by anthropogenic activities is possible by use of various kinds of fen peat products and applications. Hence, there is a strong need for new ideas for applications and alternative options for use of peat and its components, which this review seeks to provide with the suggestions for fen peat-based products and applications.

\section{Fens in the temperature zone}

Fens in the temperate zone generally are minerotrophic mires that are fed by mineralrich groundwaters and surface waters and, for a minor part, also by atmospheric precipitation [10], [11]. Fens represent multipart ecological systems and can be characterized by $\mathrm{pH}$ weak acidic, neutral or alkaline environment with rather high dissolved mineral content. The environment in fens naturally is anaerobic and/or sulphidic [12]. Fen vegetation generally is dominated by sedges, reeds and grasses but individual plant species are dependent on local water regime and nutrient concentration in groundwater [13]. The main difference between raised bogs and fens is that the latter have much higher water exchange capabilities and are less acidic. Thus, fen peat is much richer in nutrients, allowing higher vegetation to expand in fen ecosystems. The degree of differences in flora increases with the nutrient richness, tolerating the variations amongst different types of fens [14].

Fen peat is formed of fragmented, disintegrated higher plant remains. These plants have grown mostly by feeding of a mineral-rich groundwater and surface water, while atmospheric precipitation was inconsequential. The botanical composition of fen peat manifests the plant community of which it is made from, hence fen peat chemical characteristics, including the elemental composition strongly depend on chemical characteristics of peat forming plants, which, at the same time, are subjected to the feeding regime, geomorphological location, geological, geobotanical and microbial processes of the particular location [15], [16].

\subsection{Fens in relation to greenhouse gas emissions}

While natural fen ecosystems are generally greenhouse neutral in terms of active gas exchange; however, fens typically emit more greenhouse active methane than raised bogs. Even more so if fens undergo agricultural conversion and are drained. Caused by drainage, fens do not remain greenhouse gas neutral and relatively rapid release of carbon is initiated that was previously sequestered over a very long period of time; thus, fen preservation is of vital importance. The methane emissions in mires are highly variable but are generally higher in intact fens than in intact raised bogs [17]. At the same time, 
drained fens emit less methane than raised bogs and function more frequently as net sinks for atmospheric methane.

Fens every so often are used as agricultural lands but under cultivation, peat mineralisation is accelerated because of more intensive aeration of peat, therefore carbon dioxide emissions in arable fens are higher than in bogs. Simultaneously, the nitrous oxide emissions from raised bogs are low due to the low $\mathrm{pH}$ and low total nitrogen content, while in the more nutrient-rich fens higher nitrous oxide emissions have been observed. These emissions generally depend on the available nitrogen and on nitrogen fertilisation. It is assumed that $1 \%$ of the nitrogen applied as fertiliser is emitted as nitrous oxide, which has an increasing role in climate change and ozone layer stability. Nitrous oxide is 300 times more potent than carbon dioxide and depletes the ozone layer.

\subsection{Fens in Europe}

Europe has an extensive history of mire studies and peat use for many centuries, but there is still no detailed and complete map that would reflect the factual situation with mires on a global scale [18]. At the same time, these incomplete data currently are used to predict various climate change scenarios. The national datasets that are used to build a generalized version of the European mire map do not always comply with the basic mire concept, such as that used by Joosten at al. 2017 or Tannenberg et al. 2017 and thus can give only an approximate impression of the distribution of mires in particular countries but they do not reflect the definite situation [18], [19]. For instance, when viewing mire data for the Baltic States, an inconsistency can be seen - datasets for Latvia contain information last updated in 2013, for Estonia in 2011, but for Lithuania in 2004. Elsewhere, the situation is even more drastic - the data used for Ireland are from 1981, but for Romania they are from 1999. Thus, the overall picture of European mires and their conditions is highly inconsistent and alleged to be inapplicable for accurate predictions and simulations of climate change. Furthermore, data on mires for some countries are often at higher resolution to match the mapping accuracy of nearest or bordering countries and thus they are not entirely accurate either. Therefore, the exact number of fens, their current state and fen peat resources in Europe are not yet fully summarized and can be only hypothesised on. However, literature studies indicate that in the Boreal and Continental biogeographical regions of Europe, that also include the Baltic States and Latvia, the largest designated surface area ( $>60 \%)$ is covered especially by alkaline fens, the majority of them being Natura 2000 sites. The highest estimated surface area of alkaline fens in Natura 2000 is in Poland, where alkaline mires cover up to $17.1 \%$ of the total surface in Natura 2000 (24 $233 \mathrm{ha}$ ) and Estonia, where they cover up to 14.1\% (20122 ha). Latvia in this regard is in the $15^{\text {th }}$ place with $0.8 \%$ (1 $209 \mathrm{ha}$ ) and 22 documented alkaline fen Natura 2000 sites [20]. Mires in Poland cover around 1255000 ha and $92.4 \%$ of these mires are fens. However, the most of these fens (up to $70 \%$ ) are currently converted into hay meadows and grazing lands and therefore do not perform natural ecosystem functions anymore. In Estonia more than half of mires are drained and degraded, including about 120000 ha of fens, with a peat layer thicker than $0.4 \mathrm{~m}$ [21]. According to Ilomets (2017), nowadays almost all Estonian fens at some level are affected by drainage for agriculture [19], [22]. In Latvia the most intensive mire drainage was conducted between 1960 and 1980, approximately 1600000 ha was drained for agriculture but 500000 ha for forestry [23].

\subsection{Fen peat general properties}

Fen peat can be described as an organic material with diverse botanical composition, the majority of which are the remains of higher terrestrial plants with average to high decomposition degree. The high decomposition degree of fen peat manifests in high HS and lignin content, which in principle is making fen peat more fitting resource for their extraction than raised bog peat. High decomposition degree of fen peat results in a higher 
humic acid content (30 to $60 \%$ ). The fulvic acid content in fen peat, however, is comparatively lower (10 to $15 \%$ ) than in raised bog peat. While fen peat is comparatively more decomposed and contains more HS than raised bog peat, the organic matter content, comparatively, can be rather low $(<60 \%)$. This is supported by a certain impact from a number of geodynamical processes on the mineral matter supply (up to $40 \%$ of the total peat mass), which in the instance of raised bogs usually is irrelevant (1 to $5 \%$ ) when in the search for peat use.

The thickness of fen peat layer in mires can be relatively small, in comparison to other peat types. However, in fens that are not yet naturally transformed into bogs, the fen peat layer can be as thick as peat in raised bogs. Fen peat has an increased amount of the natural moisture (> $90 \%$ ); the degree of mineralisation (6 to $16 \%$ ); and the degree of decomposition is the highest among all peat types (20 to $50 \%$ ). It has also been stated that fen peat, compared to bog peat, has higher $\mathrm{pH}$ levels, ash content, nitrogen and sulphate content, amino acid and amino sugar content [24]. Fen peat every so often is dense and therefore the pore volume is negligible and the groundwater table almost reaches the surface, thus oxygen-involving processes are more limited here than in bog peat [25]. It also must be counted that current vegetation in mires initiates seasonal fluctuations of the water table and this is moving the boundary between acrotelm and catotelm and in this manner is changing peat chemical properties locally. Additionally, changes in seasonal water table in fens are frequently manifested in major increase in nitrous oxide emissions. Nutrient-rich fen peat emit comparatively higher nitrous oxide concentration than raised bogs because of higher $\mathrm{pH}$ and total nitrogen content. If fen peat is left to mineralize after raised bog peat excavation is done, fen peat oxidizes that is changing its chemical properties and consequently it results in the release of carbon dioxide, methane, nitrous oxide and other gases in the atmosphere. The elemental composition of fen peat and raised bog peat is rather similar (carbon $<60 \%$, hydrogen $<5 \%$, oxygen $<30 \%$ ) with slight differences in the nitrogen content (up to $3 \%$ in fen peat ), because of differences in peat botanical composition. Simultaneously, bitumen (4.0 to $4.5 \%$ ), cellulose (2.5 to $3.0 \%$ ) and hemicellulose (20 to $30 \%$ ) in both peats are in similar amounts. At the same time, fen peat contains more lignin (10 to $15 \%$ ), which can be isolated when extracting HS and then used in the development of various products. Although, lignin is mainly encountered in trees and bushes, all higher plants have naturally high lignin content. The exact lignin content depends on the species of plants; however, sedges and reeds found in fen peat have naturally higher lignin content than $\mathrm{m}$ [sses, which is the foundation for raised bog peat. The amount of lignin differs among different parts of plant, such as leaves, shoots, stalks, branches, trunk, and roots. Lignin has both aliphatic and aromatic portions and it transforms into humus through plant decomposition.

\section{Use of fens and fen peat}

Benefits of using fens and the natural resources found in them are known for thousands of years. Many tribes all over the world have utilized fens for food and shelter. The reeds and sedges growing in fens have been used for thatching; willow and birch barks have been used for basketry; but withered herbs, hay and lush aftermath grazing have been used for cattle [17], [26].

Fen peat itself has been used as a notable fertilizer, even before all the means used today. Fen peat with low to average ash content $(<10 \%)$ and average decomposition degree $(<25 \%)$ can be regarded as relatively favourable substrate for agricultural and horticultural production; even more so if it has weak acidic to neutral reaction with $\mathrm{pH}$ in the range between 5.5 and 7.0. In theory, fen peat substrates have high fertility rates, and those fen peat layers below thick raised bog peat deposits in raised bogs also have the absence of industrial contamination, such as heavy metals and persistent organic pollutants, which is commonly considered as a beneficial feature for agricultural and horticultural production [17]. Fen peat is the deepest and oldest peat layer in raised bogs 
and often is defined as black peat. Fen peat from raised bogs; however, is considerably different from peat in fen ecosystems. One of such differences is in fen peat density, a considerable pressure exerted by top raised bog peat layers has led to a high degree of compaction. The decomposition degree is often much higher for black peat than it is for peat in fens, this fen peat has minimal shrinkage and high water capacity and optimum air capacity. Another aspect to consider is that the extraction procedure of fen peat deposits differs from typical raised bog peat excavation. Fen peat can be extracted during spring and summer seasons, but prior to collecting it must be laid out to dry in thin layers and frozen through when collected to activate humic acid decomposition. Fen peat freezing is required to alter its structure and properties. Freezing increases fen peat volume, which in turn increases the air capacity and water storage capacity, both of which are key criteria for high quality growing mediums. The authors suggest that fen peat extraction can and should be performed in raised bogs after raised bog peat layer removal, while it is advised to leave fen ecosystems that are not yet used in any agricultural activities intact.

In comparison to raised bog peat, the product and application possibilities for raw fen peat material are different but also limited through significant compositional differences and chemical properties, which create mutually different functional properties. Comparatively though, fen peat at the bottom of raised bog peat deposits has higher industrial value than peat in fens. Fen peat contains comparatively higher content of HS, the majority of which being humic acids, and much more lignin than raised bog peat. Therefore, the authors advise that research needs to be more devoted to the search for their use but not that much on the raw material itself. At the same time, there are some potential areas, mainly in agriculture and horticulture, where fen peat could also be potentially used alongside raised bog peat.

\subsection{Fen paludicultures}

Alas, in this day and age the majority of fens worldwide are drained and converted into different types of agricultural lands and therefore no longer maintain their natural ecosystem functions, instead a notable fen peat mineralization and oxidation takes place, which complements climate change in the form of increased greenhouse gas emissions. In order to limit further negative environmental impacts, where possible, it is essential to restore these ecosystems to their original state using rewetting methods or paludicultures. Paludicultures are wet cultivations of mires. They allow to reduce greenhouse gas emissions from drained fens through their rewetting with continued land use and biomass production under constantly wet environment [Error! Reference source not found.]. By making fen peat waterlogged, paludicultures prevent carbon to bind to oxygen, and hence it cannot escape into the atmosphere as carbon dioxide. Frankly, these paludicultures can then be used in a variety of high added-value products and applications. Experiments with paludicultures in fens have already been carried out worldwide and there are many successful examples of their further use. Noteworthy is Central Europe, where fen paludicultures have been widely used in various industrial fields [27]. However, the area of use and the potential of particular paludiculture significantly depend on the conditions in particular fen ecosystem, where they are planned to be put in practice, because settings will determine what paludicultures will be possible to grow there. For instance, in oligotrophic and eutrophic fens, growing of black alders can be developed, which can then be used for furniture and timber or as fuel. In polytrophic fens, common reed growing can be carried out, which in turn can be used for animal fodder, roofing materials, paper, chemical production and fuel, including direct combustion, fermentation and conversion into pellets. Another paludiculture, which can be introduced into a rewetted fen, are bulrushes that can effectively be used for insulation and construction materials or as fuel. In polytrophic fens, also reed sweet grass can be grown, and it can then be used for fodder and fuel. Degraded eutrophic, polytrophic and base rich fens can be rewetted, and a 
variety of sedge and reed species can be then restored or introduced. For instance, reed canary grasses can be used for fodder and fuel, but sedges are usable for stable litter and as fuel. All these examples show that the restoration of fen ecosystems and the introduction of different paludicultures within them can reduce the intensity of climate change caused by greenhouse gas emissions from fens and can bring noteworthy economic benefits.

\subsection{Fen peat in agriculture and horticulture}

In theory, fen peat is more fitting for agricultural and horticultural uses than raised bog peat. This is because fen peat is often rich in minerals, nutrients ( $\mathrm{Ca}, \mathrm{Mg}, \mathrm{Na}, \mathrm{K} \mathrm{etc}$.), carbonates (>5\%) and nitrogen (>2\%). Fen peat is also less acidic than raised bog peat and the $\mathrm{pH}$ is close to the optimum range of 5.5 to 7.0. In agriculture and horticulture commonly used raised bog peat substrates, that mostly consist of Sphagnum peat, have acidic $\mathrm{pH}$ between 3.5 and 4.5 , therefore these substrates frequently require liming with horticultural grade dolomitic and calcitic limestone to enhance the $\mathrm{pH}$ to at least 5.4, at the same time, fen peat substrates technically do not require this procedure [28]. However, in practice, the fertile environment of fen peat may make it difficult to make full use of fen peat without prior treatment and thermal manipulations, including peat steaming, are required. This is because fen peat may contain relatively high amount of weed seeds that can then compete with the crops and significantly reduce their yield. These weeds compete with crops for space, sunlight, soil moisture and nutrients. Furthermore, weeds grow very vigorously with the high nitrogen levels and act as hosts for various pathogens, insects and nematodes [Error! Reference source not found.]. Fen peat also contain a variety of microorganisms, that can initiate disruptive conditions for crop development. Also, if fen peat, which is planned to be used in agriculture or horticulture, has been extracted from shallow peat layers, such as top layers in fen ecosystems, there is a possibility that it contains significant amounts of heavy metals, which can be toxic to crops. Therefore, as the best option for agricultural and horticultural applications can be considered fen peat (black peat), which is extracted from raised bog deposits after the thick raised bog peat layer has been removed. This is because black peat has been covered with a raised bog peat layer and has been in an anoxic environment for thousands of years and therefore does not contain elements of modern anthropogenic origin or fertile plant seeds.

The principal application of peat in horticulture is mainly as a growing medium, but basically only raised bog peat is used. Concurrently, fen peat (black peat) can be used as an additive to raised bog peat or tried as a standalone solution. In addition, raw fen peat can be oxidized in laboratory conditions and the resulting oxidates, due to high humic acid content, can then be applied for the treatment of various microbial and fungal diseases of agricultural crops. One of many examples here is the treatment of potato and tomato phytophtorosis [18].

The beneficial value of peat in agriculture is determined by HS and humic acids that form the majority of this organic material. Peat humic acids are known to stimulate plant growth and root development by improving substrate structure, increasing buffering capacity and preventing nutrient leaching in the applied fertilizer. Fen peat, in comparison to raised bog peat, generally contains much higher amount of humic acids and therefore the potential of their use in this context needs to be properly assessed.

\subsection{Fen peat in environmental remediation}

Due to its fertile properties, fen peat has a prospective as a topsoil substitute in recultivation of open-cast mining territories [17], [29]. Moreover, fen peat might have a cost-effective role in the remediation of degraded soils, including fens that have been previously converted into agricultural lands [29]. Fen peat also can be used in the recultivation of raised bogs, when the peat excavation is complete, and it is necessary to 
restore the natural functions of the bog. Peat material can also be used to remove oil and other petroleum products from contaminated soils through sequential remediation (bioremediation) processes by converting absorbed oils into carbon dioxide and water [30].

\section{Fen peat processing and treatment}

Peat is partially decomposed organic plant material with complex composition, it contains of lignin, cellulose, humic and fulvic acids, as well it has such functional groups as hydroxyl (alcoholic and phenolic), keto, aldehyde, carboxylic, ether, etc. Before the any application raw peat has being processed for ctablishing necessary properties for the next treatment or application [31].

\subsection{Drying}

One of the most important physical characteristics of organic soils, including peat, is high water content. Water in peat are located in pores, as mentioned before peat has great porosity, which is related to its high water content [32]. Drying of peat is commonly done with flue gases or steam at temperatures $100-400{ }^{\circ} \mathrm{C}$ for $0.5-30$ seconds. While drying peat at low temperatures and not for long time, some organic compounds are released, that cause operational problems in drying processes with formatting deposits in off-gas outlets. Usually drying rates are maxed out at $10^{\circ} \mathrm{C}$ to avoid peat pyrolysis. If temperature of drying is being significantly increased, more water and other organic compounds are released from peat mass, increasing drying temperature from $190^{\circ} \mathrm{C}$ to $350^{\circ} \mathrm{C}$ increases condensing material release from $4 \%$ to $40 \%$ of total mass, condensing material contains $2-15 \%$ water of peat mass and 2-25\% organic materials; release of non-condensing gases increased from 1 to $5 \%$ [33]. For laboratory purposes peat can be dried in drying oven at $105^{\circ} \mathrm{C}$ [34]. As shown in [31] there are a lot of functional groups and substances in peat, and losing up to $25 \%$ mass of organic materials from peat could significantly reduce chemical properties expected from processed peat, that's why optimal temperature of peat drying must be considered from further use of dried material. Peat and other organic soils can be dried, using oven-drying method. In peat drying its high porosity is unwanted characteristic, because not all of the pores are opened, some are fully/partially closed or geometrically complicated for water to escape [32], [35]. To obtain fully dried peat, high temperatures are required, but using temperatures above $100{ }^{\circ} \mathrm{C}$ charring and oxidation of organic matter and vaporization of substances other than pore water can occur. For this reason, such oven temperatures as 60-90 are recommended to avoid that. ASTM standard test method for water content determinations on peat and other organic soils (ASTM D2974) specifies an oven-drying temperature of $105 \pm^{\circ} \mathrm{C}$, which includes range of charring, oxidation and vaporization of substances [32]. In Table 1 characteristics of two type peat drying methods - fluidized bed reactor and oven drying are combined.

Table 1. Comparison between fluidized-bed reactor and oven-drying method for peat drying.

\begin{tabular}{|c|c|c|c|}
\hline \multicolumn{2}{|r|}{ Fluidized-bed reactor [33] } & \multicolumn{2}{|r|}{ Oven-drying method [32] } \\
\hline $\begin{array}{r}\text { Peat san } \\
\text { fluidiz }\end{array}$ & $\begin{array}{l}\text { nples dried at different temperatures in } \\
\text { zed-bed reactor, peat feed rate ranged } \\
110-230 \mathrm{~g} \cdot \mathrm{h}^{-1}\end{array}$ & \multicolumn{2}{|c|}{$\begin{array}{l}\text { Peat samples were dried in oven for } 6 \text { days at } 80^{\circ} \mathrm{C} \\
\text { followed by } 24 \text { h drying stages at higher temperatures } \\
\qquad\left(85-110^{\circ} \mathrm{C}\right) \text { and weighted }\end{array}$} \\
\hline $\begin{array}{c}\text { Tem- } \\
\text { perature }\end{array}$ & Processes & $\begin{array}{c}\text { Tem- } \\
\text { perature }\end{array}$ & Results \\
\hline $190^{\circ} \mathrm{C}$ & $\begin{array}{c}4 \% \text { release of condensing mass }(1.5 \% \\
\text { water }+2.5 \% \text { organic compounds) from } \\
\text { peat mass, } 1 \% \text { release of } \\
\text { non-condensing gases }\end{array}$ & $80^{\circ} \mathrm{C}$ & $\begin{array}{l}\text { Peat dry mass reduced average by } 0.5 \% \\
\text { (from } 4.715 \text { to } 4.685 \mathrm{~g} \text { ) }\end{array}$ \\
\hline
\end{tabular}


$21 \%$ release of condensing mass ( $5 \%$

$250{ }^{\circ} \mathrm{C}$ water $+15 \%$ organic compounds) from peat mass, $2.5 \%$ release of non- condensing gases

$25 \%$ release of condensing mass (11\% $300^{\circ} \mathrm{C}$ $350{ }^{\circ} \mathrm{C}$ water $+14 \%$ organic compounds) from peat mass, $5 \%$ release of non-condensing gases

$40 \%$ release of condensing mass (15\% water $+25 \%$ organic compounds) from peat mass, $7 \%$ release of non-condensing gases
$90{ }^{\circ} \mathrm{C}$

Peat dry mass reduced average by $0.75 \%$ (from 4.685 to $4.650 \mathrm{~g}$ )

$100{ }^{\circ} \mathrm{C} \quad$ Peat dry mass reduced average by $0.5 \%$ (from 4.650 to $4.625 \mathrm{~g}$ )

Peat dry mass reduced average by $0.4 \%$ (from 4.625 to $4.605 \mathrm{~g}$ )

Peat dry mass reduced average by $1.1 \%$ (from 4.605 to $4.555 \mathrm{~g}$ )

From this comparison it can be concluded that oven-drying method is less efficient than fluidized-bed reactor, because mentioned in [32] peat mass can have up to $1000 \%$ water, and decrease of peat weight in oven-drying is minimal.

There are several approaches of peat milling, depending on the way how peat is mined. Surface peat mining - peat milling is the first step, done in the peatland. First of all, field must be drained to avoid from unnecessary water in peat. Milling is done because peatland consists mostly of peat, but also of small wood residues, roots of trees, shrubs, parts of grass and moss vegetation, woodchips, peat of small decomposition degree - all these components are milled and the whole layer of milled components are removed from the field [36]. For large scale peat fuel milling such devices as passive miller, active screw miller and active knife miller are used. Mostly peat is milled on field and dried there; rarely it's collected, moved and then milled. Usually milling devices are attached to heavy machinery (tractors) and milled on the field [37]. For laboratory purposes peat can be milled with centrifugal mill, grinding peat into homogeneous fine powder. Using centrifugal mill some metallic particles of mill can be found in peat, for an example titanium centrifugal mill is not recommended for such applications as peat milling [34].

\subsection{Dispersing in a water}

In order to extract compounds from peat, suspension with water can be made. Peatwater suspension consists of different size particles and liquid state - water with different solutes [38]. Peat suspension can be separated in several different ways - filtration, centrifugation, sedimentation, membrane separation [39]. Separation of peat can be performed using density gradient centrifugation (DGC). Peat compound molecules have small molecular weight $\left(<10^{-6} \mathrm{~kg} \cdot \mathrm{mol}^{-1}\right)$ most important characteristics for successful separation are are banding density, sedimentation rate, particle size and shape, and concentration range of interested compound(s). For industrial size peat separation slurry raw material (peat) is added to the acidic solution and stirred until the $\mathrm{pH}<2$, the acidic solution is stopped, with $\mathrm{pH}$ 2-7. Then the acidic slurry is introduced to alkaline solution and stirred until the $\mathrm{pH}>10$, then addition of the alkaline solution is stopped. Further slurry is introduced again with acidic solution and mixed, until $\mathrm{pH}$ is about 7 (neutral), slurry is filtered. Liquid part is passed through dryer at temperature $100-300{ }^{\circ} \mathrm{C}$ to obtain solid compound, solid part is vacuum smelted to obtain solid material. Both solid components are chemically treated. Originally this method is meant for coal purification, but also can be performed for peat separation and purification [40].

\subsection{Separation}

Spray drying, sedimentation, microfiltration and ultracentrifugation could be used for peat suspension separation can be used as. In spray drying suspension is sprayed through injector, achieving droplets $100 \mu \mathrm{m}$ in diameter, which further are dried in flow 
of hot gas. Result is spherical particles in about $1 \mathrm{~mm}$ in diameter [41]. Sedimentation can be carried out by suspending peat particles in viscous liquid and letting for particles to settle under gravitational force; different size and mass particles settle in different rate [42]. In microfiltration membrane with $0.1 \mu \mathrm{m}-10 \mu \mathrm{m}$ wide pores are used to seperate suspension, which is flowing over membrane (in cross flow) letting for the smallest particles to seperate [43]. Ultracentrifugation is based on differences of particle mass, density, shape, viscosity and density of solvent and centrifugal acceleration. Two ultracentrifugation methods are used: analytical and preparative ultracentrifugation. Analytical ultracentrifugation is used to determine different parameters of compound (molar mass, shape of particle, sedimentation and diffusion coefficient), preparative ultracentrifugation is used for isolation of specific particles from whole mixture [44].

\subsection{Homogenisation}

In order to homogenize peat, it's suspension with water is made. Peat suspension homogenization can be carried out in many different ways - high-speed mixer-dispenser, ultrasound cavitation, (ultra) high-pressure cavitation. The main reason for peat homogenization is to obtain as many soluble components from peat-water suspension, by homogenizing peat particles in suspension are smaller, which means greater compound outcome in suspension [38], [45] By (ultra) high pressure cavitation it is possible to homogenize peat, but by using such method microbial load is decreased - some valuable organic compounds of peat could be damaged [45]. Optimal way to homogenize peat is by using high-speed mixer-dispenser. In [38] it is shown that from homogenized peat suspension humic and fulvic acids can be extracted approximately $30 \%$ more than from basic peat suspension. Only drawback is that cavitation shears larger humic acid molecules into smaller fulvic acids. Cavitation for peat suspension is done with several cavitation cycles, high-speed mixer-dispenser reaches its maximum efficiency after 3 cavitation cycles with significant increase in quantity of finer particles [38].

Peat dispersion can be done applying hydrodynamic cavitation process, in which peat is crushed (milled), applying diffusion, dissolving humic substances and dissolving them in a leaching solution. Dispersion process also includes high-speed mixer-dispenser, where dispersion in the presence of cavitation effects by impacts in a liquid media occurs [38], [46].

In conclusion best way of full peat processing can be preferred - for peat drying it would be recommended to use fluidized-bed reactor with temperature approximately $250{ }^{\circ} \mathrm{C}$, because below this temperature a lot of water does not evaporate, but over this temperature a lot of organic compounds evaporate. For peat milling traditional method is recommended - milling on the field, if it is necessary to obtain fine particles, then centrifugal mill can be used. Peat separation is complicated question, but one of the easiest ways to separate peat suspension is ultracentrifugation, because chemical treatment is not strongly required and only one device is necessary. For peat homogenization, and also for dispersion high-speed mixer-dispenser is best option, because both - homogenization and dispersion is done at once, and compared to other homogenization and dispersion methods using high-speed mixer-dispenser is a lot more suitable for large scale production. As well such conclusion can be made - peat treatment can be done in lot of different ways and examples for A-Z complete overview cannot be found, that shows topicality for such complete overview.

\subsection{Peat pyrolysis}

According to Bogdashov et al. [47], Krapivnitckaia et al. [48] and Cunico [49] pyrolysis is thermochemical decomposition process of organic compounds obtained by heating in oxygen absence. By Bogdashov et al. [47] the yield of solid, liquid and gaseous substances depends on the chemical composition of the feedstock and the physicochemical conditions of the reaction, e.g. temperature, pressure, degree of oxygen 
presence, etc. And by Cunico [49] the pyrolysis product yield can be influenced by temperature, heating rate, material size and shape, and residence time in the reactor. Peat pyrolysis products are: pyrolysis gas, oily fraction and carbon residue [47]. The products of peat (and biomass in common) pyrolysis are:

a gaseous fraction (contains $\mathrm{H}_{2}, \mathrm{H}_{2} \mathrm{O}, \mathrm{CO}, \mathrm{CO}_{2}, \mathrm{HCs}\left(\mathrm{CH}_{4}, \mathrm{C}_{2} \mathrm{H}_{4}, \mathrm{C}_{3} \mathrm{H}_{6}\right)$ );

a liquid oil fraction (contains $\mathrm{H}_{2} \mathrm{O}$, tar and $\mathrm{OCs}$ with low molecular weight, e.g. acids, aldehydes, alcohols, chitons);

a solid residues with high molecular weight (carbon residues, ashes, inert and metallic species) [49].

\subsubsection{Peat pyrolysis parameters}

\subsubsection{Temperature}

The main parameter of pyrolysis is temperature. It determines the degree of destruction of raw materials and the composition of pyrolysis products. As the temperature rises, the ratio between the yields of decomposition products changes: the yield of liquid and solid residues decreases, and the yield of gases increases (Figure 1) [47]. Duan et al. [50] found that with increasing heating temperature, total gas and $\mathrm{CH} 4$ yields gradually increases. In turn, Salgansky et al. [51] claimed that the heating rate and the temperature are the main factors which influence thermal decomposition of biomass. Regardless of other conditions, it is widely known that an increase in pyrolysis temperature always increases fuel degradation. Tabakaev et al. [52] claimed that when the temperature of pyrolysis varies by several tens of degrees, the yield of products varies insignificantly.

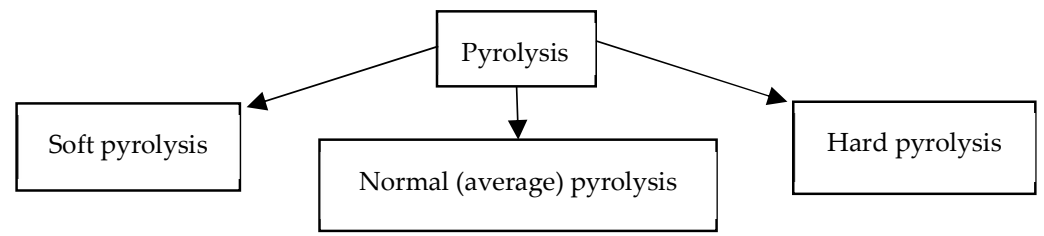

Figure 1. Types of pyrolysis according to Bogdashov et al. [47], authors drawing.

In order to obtain more valuable pyrolysis products with high coke yields, Cunico [49] recommended to realize peat sample pre-treatment at low temperature.

\subsubsection{Particle size}

In accordance to Cunico [49] and Tabakaev et al. [53] research, the product yield is affected by the size of the peat fraction. Salgansky et al. [51] experiments have shown that the smaller the particle size, the higher the yield of tar. In addition, larger pyrolysis products remain longer at higher temperatures than smaller pyrolysis products. In Cunico study [49] it was found that with an increase in the particle size from $0.05 \mathrm{~mm}$ to $2.0 \mathrm{~mm}$, the tar yield increases by about $5 \%$, the coke yield by $4 \%$ (in the range of $0.1-0.4 \mathrm{~mm}$ ), and the gas yield decreased by $11.5 \%$. Tabakaev et al. [53] recommends using particles of $0.2-$ $1.0 \mathrm{~mm}$.

\subsubsection{Pressure}

Cunico [49] claimed that reduced pressure during pyrolysis ( $\leq 10 \mathrm{~mm} \mathrm{Hg}$ ) allows to obtain a higher yield of tar than operating at atmospheric pressure, but at the same time, lower yields of other products. But the calorific value of semi-coke at reduced pressure is lower. In turn, Morgalla [54] proved that increasing the pressure or retention time during pyrolysis also decreases the surface area of the char and its reactivity. But in obedience to Duan et al. [50] many previous experiments have been carried out at normal pressures, so the pyrolysis under high pressure would be better suitable to simulate natural conditions.

\subsubsection{Heating rate}


Basically, in accordance to Cunico [49] the heating rate of peat is taken into account in slow pyrolysis, because with fast pyrolysis, the raw material instantly reaches the desired temperature and the main parameter is the residence time. Low heating rates during fast pyrolysis reduce the yield of gases and vapors and increase the carbon content in the char. However Salgansky et al. [51] claimed that the more rapid heating, the higher tar yield and the lower yield of char residue.

Klein et al. [55] found that the heating rate of the sample significantly affects the volatilization of $\mathrm{C}$ - and N-containing compounds. However, the heating rate and temperature rise had a stronger effect on the $\mathrm{N}$ efficiency. Sample weight was not a major factor in pyrolysis efficiency. So, $\mathrm{N}$ pyrolysis was higher than $\mathrm{C}$ pyrolysis efficiency (Table 2).

Table 2. Average $\mathrm{C}$ and $\mathrm{N}$ pyrolysis efficiency in units of percent $\mathrm{C}$ or $\mathrm{N}$ by mass volatilized (modified from [55]).

\begin{tabular}{cccccccccc}
\hline Temperature, $^{\circ} \mathrm{C}$ & \multicolumn{3}{c}{$\mathbf{6 0 0}$} & \multicolumn{3}{c}{$\mathbf{8 0 0}$} & \multicolumn{3}{c}{$\mathbf{9 5 0 / 9 9 0}$} \\
\hline${\text { Heating rate, } \mathrm{K} \cdot \mathrm{min}^{-1}}^{10}$ & 20 & 50 & 10 & 20 & 50 & 10 & 20 & 50 \\
$\mathrm{C}$ & 46.6 & 48.6 & 50.0 & 46.2 & 47.9 & 48.7 & 45.3 & 45.1 & 48.7 \\
$\mathrm{~N}$ & 58.4 & 56.7 & 60.9 & 67.7 & 69.3 & 70.5 & 72.5 & 75.8 & 75.5 \\
\hline
\end{tabular}

4.5.1.5. Residence time

By Cunico [49] the duration of pyrolysis is important because it can provoke secondary reactions such as re-condensation (likely at a slow heating rate), repolymerization or cracking. These reactions are influenced by two factors: the heating rate and the partial pressures of the gases. The coke yield is increased by increasing the processing time (Table 3). If the residence time is less than $0.1 \mathrm{~s}$, then the type of pyrolysis is fast, if more, then slow. Maryandyshev et al. [56] experiments showed that the yield of volatile substances in an inert $\left(\mathrm{N}_{2}\right)$ atmosphere increased with the residence time of peat particles in the reaction zone.

According to Maryandyshev et al. [56] the process of peat fuel pyrolysis at a heating rate of $5{ }^{\circ} \mathrm{C} \cdot \mathrm{min}^{-1}$ begins at $200-220^{\circ} \mathrm{C}$ and ends in the temperature range of $500-570{ }^{\circ} \mathrm{C}$. The process of peat pyrolysis occurs in a wide range of temperatures, at which the DTG curve has two peaks at temperatures of $293{ }^{\circ} \mathrm{C}$ (characterizes the release and combustion of volatile substances) and $405^{\circ} \mathrm{C}$ (the process of burning the carbon matrix). According to Melenevskii et al. [57] the $\mathrm{HC}$ releases at the low temperature $\left(<300^{\circ} \mathrm{C}\right)$ step, intermediate-temperature $\left(300-400^{\circ} \mathrm{C}\right.$ ) step produced by kerogen decomposition and high-temperature one $\left(>400{ }^{\circ} \mathrm{C}\right)$.

Table 3. Mass percentages of the products for each type of pyrolysis (modified Cunico [49]).

\begin{tabular}{|c|c|c|c|}
\hline & $\begin{array}{l}\text { Gaseous } \\
\text { fraction }\end{array}$ & $\begin{array}{l}\text { Liquid } \\
\text { fraction }\end{array}$ & Char \\
\hline $\begin{array}{c}\text { Slow pyrolysis } \\
\text { Low-moderate temperature } \\
\text { Long residence time }\end{array}$ & $35 \%$ & $\begin{array}{c}30 \%(70 \% \\
\text { water) }\end{array}$ & $35 \%$ \\
\hline $\begin{array}{c}\text { Intermediate pyrolysis } \\
\text { Low-moderate temperature } \\
\text { Moderate hot vapour residence times }\end{array}$ & $25 \%$ & $\begin{array}{c}50 \%(50 \% \\
\text { water) }\end{array}$ & $25 \%$ \\
\hline Fast pyrolysis & & $75 \%$ & \\
\hline $\begin{array}{c}\text { Moderate temperature }\left(500^{\circ} \mathrm{C}\right) \\
\text { Short hot vapour residence time }(<2 \mathrm{~s})\end{array}$ & $13 \%$ & $\begin{array}{c}(25 \% \\
\text { water })\end{array}$ & $12 \%$ \\
\hline
\end{tabular}

According to 
Table 3, the maximum yield of gases and char is obtained with slow pyrolysis, while

\begin{tabular}{|c|c|c|c|}
\hline & $\begin{array}{l}\text { Gaseous } \\
\text { fraction }\end{array}$ & $\begin{array}{c}\text { Liquid } \\
\text { fraction }\end{array}$ & Char \\
\hline $\begin{array}{c}\text { Slow pyrolysis } \\
\text { Low-moderate temperature } \\
\text { Long residence time }\end{array}$ & $35 \%$ & $\begin{array}{c}30 \%(70 \% \\
\text { water) }\end{array}$ & $35 \%$ \\
\hline $\begin{array}{c}\text { Intermediate pyrolysis } \\
\text { Low-moderate temperature } \\
\text { Moderate hot vapour residence times }\end{array}$ & $25 \%$ & $\begin{array}{c}50 \% \text { (50\% } \\
\text { water) }\end{array}$ & $25 \%$ \\
\hline $\begin{array}{c}\text { Fast pyrolysis } \\
\text { Moderate temperature }\left(500^{\circ} \mathrm{C}\right) \\
\text { Short hot vapour residence time }(<2 \mathrm{~s})\end{array}$ & $13 \%$ & $\begin{array}{l}75 \% \\
(25 \% \\
\text { water })\end{array}$ & $12 \%$ \\
\hline
\end{tabular}

the yield of the obtained liquid fraction is higher with fast pyrolysis. But the maximum yield of tar is at a temperature range of $250-500{ }^{\circ} \mathrm{C}$ [49].

\subsubsection{Microwave pyrolysis}

One of the most promising from an ecological point of view processes is microwave pyrolysis, where microwave energy is converted into heat in materials with low thermal conductivity was described in Bogdashov et al. [47] and Krapivnitckaia et al. [48] studies. The advantage of this method is that it is possible to quickly adjust the reaction rate and the composition of the products, while the traditional pyrolytic reactor with surface heating of peat requires a long reaction time and does not provide heating uniformity. Krapivnitskaia et al. [58] found out that the mass fraction of carbon after microwave pyrolysis more than doubled. So, this method is more efficient than traditional heating methods, because it can significantly increase the pyrolysis rate, as well as increase the output of combustible gases. There is a possibility of creating a closed power cycle of the device and its autonomous operation. According to Bogdashov et al. [47] the use of microwave heating has great potential for further use in pyrolysis reactions. As a result of chemical analysis of the composition of gases released during microwave pyrolysis, it was found that they do not contain heavy toxic gases that are present after traditional thermal pyrolysis.

\subsubsection{Generalized conclusions on the peat pyrolysis}

In Indrawati et al. [59] work, the pyrolysis of peat was carried out at $350{ }^{\circ} \mathrm{C}$ with different pyrolysis times $(3,4,5 \mathrm{~h})$. Macro- and micropore analysis has shown that they are strong and ordered, but their size is partially destroyed, so they cannot be measured. And in order to obtain a sorbent Klavins and Porshnov [60] found out that the optimal pyrolysis mode can be considered peat recycle at $250{ }^{\circ} \mathrm{C}$ for $6 \mathrm{~h}$, because processing at temperatures above $250^{\circ} \mathrm{C}$ is associated with a loss of mass and a change in the structure of peat. However, an increase in the pyrolysis temperature improves the hydrophobic and oleophilic properties of peat after $4 \mathrm{~h}$ of treatment.

According to Morgalla [54] high heating rates generally increase the surface area and pore volume of the peat. Klavins and Poshnov [60] studied changes in the structure of peat during pyrolysis, which showed that the surface area of peat before low-temperature pyrolysis was approximately $12-74 \mathrm{~m}^{2} \cdot \mathrm{g}^{-1}$, and after it was $120-160 \mathrm{~m}^{2} \cdot \mathrm{g}^{-1}$. In addition, by Tolvanen et al. [61] the particles of the peat sample retained their elongated shape.

Lee et al. [62] investigated the influence of $\mathrm{CO}_{2}$ and $\mathrm{N}_{2}$ on the char surface area. In this study peat was pyrolyzed from 20 to $650{ }^{\circ} \mathrm{C}$ at the heating rate of $10^{\circ} \mathrm{C} \cdot \mathrm{min}^{-1}$, and then isothermally pyrolyzed for $10 \mathrm{~min}$. A higher surface area was obtained in $\mathrm{PB}-\mathrm{CO}_{2}$ compared to $\mathrm{PB}-\mathrm{N}_{2}$, which means that $\mathrm{CO}_{2}$ plays a special role in stimulating the formation of pores on the surface of the char (Fig. 2). It was found that the $\mathrm{CO}_{2}$-assisted fast pyrolysis process can be used to produce a high quality bio-oil. Shumovskii et al. [63] 
found that the mechanical activation of peat increases the yield of semicoke and its mechanical strength.
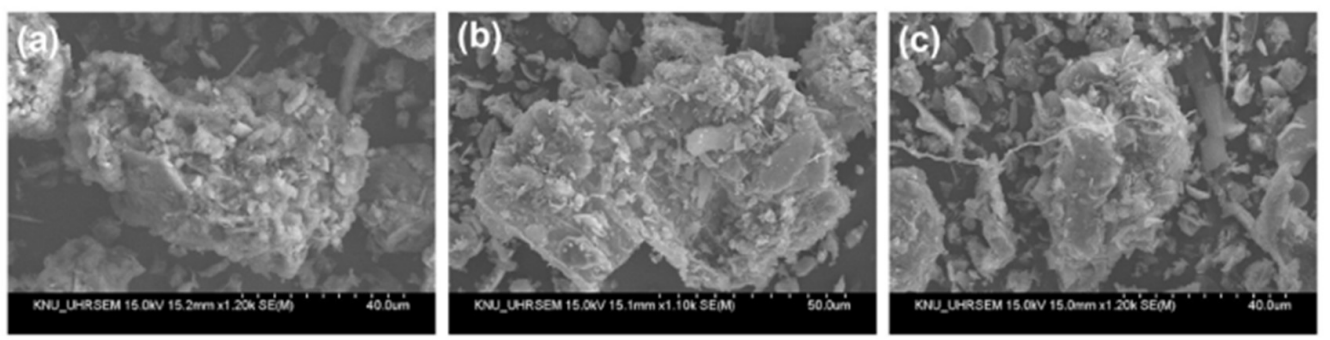

Fig. 2. The morphology of peat and peat-biochars. SEM images of (a) peat, (b) PB-N2, (c) PB-CO2 according to Lee et al. [62]

In accordance to Wiśniewska et al. [64] the obtained char was subjected to physical activation with $\mathrm{CO}_{2}$ steam $800{ }^{\circ} \mathrm{C}$ to about $50 \%$ of burn-off. As a result the peat surface area was $706 \mathrm{~m}^{2} \cdot \mathrm{g}^{-1}$.

Generalized information on the methods of peat pyrolysis is included in Table 4, Table 5 and Fig. 3.

Table 4. Peat pyrolysis parameters and product yields.

\begin{tabular}{|c|c|c|c|c|c|c|c|}
\hline Peat sample & $\begin{array}{l}\mathbf{t}_{\text {pyrolysis, }} \\
{ }^{\circ} \mathrm{C}\end{array}$ & $\begin{array}{l}\text { Pyrolysis } \\
\text { time, min }\end{array}$ & $\begin{array}{l}\text { Heating } \\
\text { rate }\end{array}$ & $\begin{array}{c}\text { Gas } \\
\text { yield, } \\
\% \\
\end{array}$ & $\begin{array}{c}\text { Oily } \\
\text { frac- } \\
\text { tion, } \% \\
\end{array}$ & $\begin{array}{c}\text { Carbon } \\
\text { residue/c } \\
\text { har, } \%\end{array}$ & Ref. \\
\hline $\begin{array}{c}\text { Dried in a thermostat at } \\
40-50{ }^{\circ} \mathrm{C} \text {, particle size }< \\
0.2 \mathrm{~mm}, 200 \mathrm{~g}\end{array}$ & $\begin{array}{l}350 \\
400 \\
450 \\
500 \\
550\end{array}$ & n. d. & $\begin{array}{c}10 \\
\mathrm{~K} \cdot \mathrm{min}^{-1}\end{array}$ & $\begin{array}{c}8.8 \\
14.5 \\
17.1 \\
21.9 \\
29.7\end{array}$ & $\begin{array}{l}14.9 \\
31.5 \\
36.6 \\
36.8 \\
33.8\end{array}$ & $\begin{array}{c}70.3 \\
54.0 \\
46.3 \\
41.3 \\
36.5 \\
\text { Semicoke }\end{array}$ & [63] \\
\hline $\begin{array}{l}\text { Low-moor peat, particle } \\
\text { size } 0.2-1.0 \mathrm{~mm} \\
\text { Dried in an oven at } \\
105^{\circ} \mathrm{C} \text { for } 24 \mathrm{~h} \text {, particle } \\
\text { size } \sim 0.1 \mathrm{~mm}\end{array}$ & $\begin{array}{l}20-550 \\
700 \\
850 \\
900\end{array}$ & $\begin{array}{l}80 \\
30\end{array}$ & $\begin{array}{c}10^{\circ} \mathrm{C} \cdot \mathrm{mi} \\
\mathrm{n}^{-1} \\
\text { n. d. }\end{array}$ & $\begin{array}{l}9.58- \\
15.49 \\
68.60 \\
72.49 \\
76.86\end{array}$ & $\begin{array}{l}12.75- \\
19.66 \\
\text { n. d. }\end{array}$ & $\begin{array}{l}64.85- \\
77.67 \\
\text { n.d. }\end{array}$ & [61] \\
\hline $\begin{array}{l}10 \mathrm{~g} \text { of peat moistened } \\
\text { with water } 1: 1(\mathrm{v}: \mathrm{v})\end{array}$ & $\begin{array}{l}100-150 \\
200 \\
225 \\
250 \\
275 \\
300\end{array}$ & $\begin{array}{c}240 \\
240 \\
240 \\
120-600 \\
240 \\
240\end{array}$ & n. d. & n. d. & n. d. & $\begin{array}{c}100 \\
85 \\
80 \\
85-48 \\
45 \\
35\end{array}$ & [60] \\
\hline
\end{tabular}

Table 5. Peat pyrolysis parameters and product weight loss (\% of total mass).

\begin{tabular}{|c|c|c|c|c|c|c|}
\hline \multirow[t]{2}{*}{ Peat sample } & \multirow{2}{*}{$\overline{\text { teyrolysis, }}^{\circ}$} & \multirow{2}{*}{$\begin{array}{c}\text { Heating } \\
\text { rate, }^{\circ} \mathrm{C} \cdot \mathrm{min}^{-1}\end{array}$} & \multicolumn{3}{|c|}{ Weight loss, \% (of total mass) } & \multirow[t]{2}{*}{ Ref. } \\
\hline & & & Gas, \% & $\begin{array}{l}\text { Carbon } \\
\text { residue, \% }\end{array}$ & $\begin{array}{l}\text { Residue } \\
\text { mass, \% }\end{array}$ & \\
\hline \multirow{2}{*}{$\begin{array}{l}\text { Air-dry peat (dried in an oven at } \\
105^{\circ} \mathrm{C} \text { ), particle size }<3 \mathrm{~mm}, 16 \mathrm{mg}\end{array}$} & \multirow{2}{*}{$25-1000$} & $\begin{array}{c}\text { Ar flow } \\
\left(50 \mathrm{ml} \cdot \mathrm{min}^{-1}\right) \\
\left.5^{\circ} \mathrm{C} \cdot \mathrm{min}^{-1}\right)\end{array}$ & $\begin{array}{l}(130- \\
\left.500^{\circ} \mathrm{C}\right)\end{array}$ & $\begin{array}{c}(500- \\
\left.1000^{\circ} \mathrm{C}\right)\end{array}$ & & \multirow{2}{*}{ [65] } \\
\hline & & $\begin{array}{l}10^{\circ} \mathrm{C} \cdot \mathrm{min}^{-1} \\
20^{\circ} \mathrm{C} \cdot \mathrm{min}^{-1}\end{array}$ & $\begin{array}{l}40.6-47.4 \\
41.4-52.1 \\
42.1-53.3\end{array}$ & $\begin{array}{l}6.8-7.6 \\
4.5-6.3 \\
4.6-6.4\end{array}$ & $\begin{array}{l}36.4-44.0 \\
35.8-43.5 \\
33.6-43.2\end{array}$ & \\
\hline
\end{tabular}


Dried at $80^{\circ} \mathrm{C}$ for $24 \mathrm{~h}$ in an oven, particle size of $0.15-0.45 \mathrm{~mm}, 5-10 \mathrm{mg}$

Freeze-dried at $-40^{\circ} \mathrm{C}$ for 7 days; in vacuum oven at $25^{\circ} \mathrm{C}$ until constant mass was achieved; $10 \mathrm{mg}$

Air-dry peat (dried in an oven at $\left.105^{\circ} \mathrm{C}\right)$, particle size $<3 \mathrm{~mm}$
He flow $\left(50 \mathrm{ml} \cdot \mathrm{min}^{-1}\right)$ $5^{\circ} \mathrm{C} \cdot \mathrm{min}^{-1}$

24-800 $\quad 10^{\circ} \mathrm{C} \cdot \mathrm{min}^{-1}$ $15^{\circ} \mathrm{C} \cdot \mathrm{min}^{-1}$ $20^{\circ} \mathrm{C} \cdot \mathrm{min}^{-1}$ $30{ }^{\circ} \mathrm{C} \cdot \mathrm{min}^{-1}$ $\left(50 \mathrm{ml} \cdot \mathrm{min}^{-1}\right)$ $10^{\circ} \mathrm{C} \cdot \mathrm{min}^{-1}$

Ar atmosphere $5 \mathrm{~K} \cdot \mathrm{min}^{-1}$ $10 \mathrm{~K} \cdot \mathrm{min}^{-1}$ $20 \mathrm{~K} \cdot \mathrm{min}^{-1}$

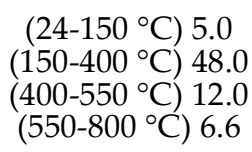

$\left(25-155^{\circ} \mathrm{C}\right) 1.0-1.8$

$\left(155-380^{\circ} \mathrm{C}\right)$ 23.4-24.7

$\left(380-615^{\circ} \mathrm{C}\right)$ 20.4-25.1

$\left(615-900{ }^{\circ} \mathrm{C}\right)$ 11.6-15.9

(Residue mass at $900{ }^{\circ} \mathrm{C}$ : $33.8-42.3 \%)$

$\left(25-150{ }^{\circ} \mathrm{C}\right) 8.0$

$\left(150-540{ }^{\circ} \mathrm{C}\right) 46.0$

$\left(500-1000{ }^{\circ} \mathrm{C}\right) 6.5$

(Residual mass upon reaching $1000{ }^{\circ} \mathrm{C}$ : $35-44 \%$

\section{$\mathrm{t},{ }^{\circ} \mathrm{C} ; \tau, \min$}

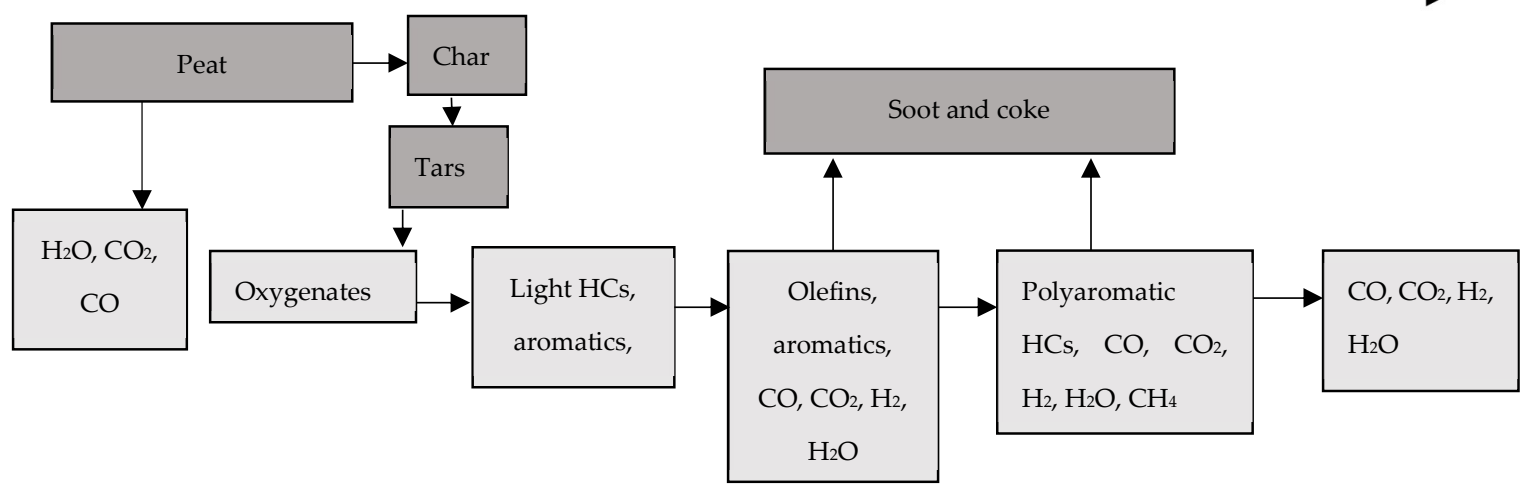

$\begin{array}{lll}\text { I process } & \text { II process } & \text { III process }\end{array}$

Fig. 3. Peat pyrolysis products as a function of temperature and time according to Morgalla [54], author's drawing.

In accordance to obtained data the most optimal and effective peat pyrolysis method include: thermal pre-treatment of peat (at $\sim 100{ }^{\circ} \mathrm{C}$ in an oven) to constant mass, milling to the particle size $0.2-1.0 \mathrm{~mm}$. Further processing of peat depends on the desired pyrolysis products. As the temperature rises the yield of liquid and solid residues decreases, and the yield of gases increases. To get more tar, it is recommended to use a pyrolysis temperature of $250-500{ }^{\circ} \mathrm{C}$. In turn, to obtain char and gases, it is important to use low and high temperatures, respectively. Maximum yield of gases and char is obtained with slow pyrolysis, while the yield of the obtained liquid fraction is higher with fast pyrolysis. Optimal heating rate is $10^{\circ} \mathrm{C} \cdot \mathrm{min}^{-1}$.

\subsection{Industrial use of fen peat}

Raw fen peat material itself has low industrial value and it requires chemical and thermal processing prior usage in most products and applications. However, it can be used for the production of sorbent applications. Furthermore, fen peat as an additive can improve properties of a variety materials, such as building and insulation constituents [17], [69].

4.6.1. Production of activated charcoal 
One of the options for raw fen peat material is the production of activated charcoal. The activated charcoal is effective in a number of applications, including soil and water purification from a variety of organic and inorganic contaminants, it can also be used in a variety of health and hygiene care products, such as skin care and oral care [70], [71]. The elemental composition of fen peat contains approximately $60 \%$ of carbon that can be activated through pyrolysis, chemical methods or water steam.

\subsubsection{Fen peat as insulation material}

Thermally pre-treated and grinded fen peat can be combined with tar and gypsum and then be used as an insulation material in construction. Peat and wood-based thermal insulation model materials using fen peat as binder have already been constructed and shown some notable results [72], [73].

Fen peat can be described as a composite multi-component system. Part of fen peat material (bitumens and waxes) has hydrophobic properties, while another part (lignin and humin) has hydrophilic properties. Fen peat contains semi-colloidal macromolecular compounds that have micro-mosaic heterogeneity and act as polyelectrolytes. Fen peat is dominated by R-OH-R-COO- type negative load functional groups, hence when fen peat is used as binder it is required for the foaming agents to have the opposite (positive) charge [73].

\subsubsection{Fen peat in air filtration systems}

Biological air filtration applications are becoming more popular due to their relatively high efficiency and low cost [74]. Fen peat can theoretically be used in these filtration systems. Fen peat can transform and absorb most molecules that cause odours and release gaseous pollutants in the air, such as ammonia, hydrogen sulphide or methane [75]. In this matter also activated charcoal, that can be made of fen peat, can be used.

\subsection{Fen peat-based medical applications}

Fen peat is highly decomposed organic material and has high thermal capacity, which in turn can be proficiently used in the physiotherapy [17]. Thermal abilities of fen peat applications can promote relaxation and stimulate the blood flow. Furthermore, fen peat contains trace metals, vitamins, carbohydrates, polyphenols, lipids and humic acids, all of which have highly beneficial medial significance. Such as peat oxidates, which have been found to be helpful not only in agriculture and horticulture, but also in the treatment of skin diseases. Compounds combining these volatiles with water steam can also be used in the eye disease treatment. Moreover, fen peat can be used in fomentations on account of low thermal conductivity and high heat capacity [17], [76].

\subsection{Fen peat in veterinary}

The potential of peat as a food supplement for animals has only been thoroughly studied from the aspect of HS effects, yet without separating amongst peat types. The HS are natural elements of the food chain and are present in all plant and animal organisms. However, it is not yet clear whether any other substances, besides HS that are present in peat can employ adversative effects to living organisms [77]. At the same time, benefits of humic acids are explored in high detail and they are used, for instance, in aquaculture. Because of high humic acid concentration, fen peat substrates can significantly improve growth conditions for aquatic plants and fish reproductive system. In addition, fen peat contains relatively high content of fulvic acids, which can protect fish mucous membranes from bacterial illnesses [78]. Fen peat humic acids can strengthen fish immune response. Moreover, humic acid-containing substrates can limit algal prevalence, hence fen peat can be used for water filtration, but fen peat preparations can be added as water softeners to fish tanks. The material that is most often used in the water filter units is granulate activated charcoal, which can be made through the activation of carbon that is found in fen peat. 


\section{Use of fen peat humic substances}

The major part of peat HS consist of humic acids. Fen peat humic acids form roughly 30 to $60 \%$ of the total composition, which is rational amount for industrial extraction and efficiently can be used in agricultural and horticultural applications, as well as in the preparation of food additives and supplements with growth-stimulating, fungicidal and bactericidal properties. These additives can prolong food digestion and hence improve nutritional intake. The humic acid preparations can work as immunological stabilizers, nutrient yeasts, carbohydrate fodder additives and absorbents for harmful substances. Moreover, fen peat humic acids can limit the frequency of intestinal diseases and accelerate muscle mass growth and strengthen the immune system. Different humic acid preparations can be used for the treatment of arthritis, back pain, orthopaedic diseases and neurological disorders. The humic acid fomentations can be used to overheat selected body parts, increase blood circulation and promote the destruction of metabolic waste. The humic acids have the potential to positively affect human immune system as they can both activate and inhibit various biological processes. Additionally, they are effective against bacteria, viruses and inflammation and thus can be efficiently used in the preparation of remedies. Some humic acids (HA) applications have been found to be inhibitors for corrosion and can transform rust into metal, for instance, in Belarus, they have been used to remove rust from automobiles [79].

\subsection{Extraction of humic and fulvic substances from peat}

Extraction of HS (HS) involves 3 main stages: preparation of peat samples, extraction, and separation. The preparatory part includes sampling peat from different layers of peat soil, acid treatment and drying of peat. In turn, the extraction can be carried out at different temperatures, stirring conditions, $\mathrm{pH}$ and extraction time. In order to separate the obtained HA and fulvic acids (FA), acidification of the extract with subsequent centrifugation is widely used.

Preparation of peat samples

The classic approach to sampling is as follows: obtaining samples from different depths of peat soil. So, the amount of HS in peat can be influenced by the depth of the soil samples taken.

In accordance with Lodygin et al. [80] each layer of peat soil can be characterized by a different botanical composition, temperature and rate of transformation of soil organic matter, as well as, importantly, different structural and functional composition of humic acids [80]. According to Krumins et al. [81] the amount of humic acids from bog peat depends on the characteristics of the area, amount of organic and mineral matter in the soil and the efficiency of extraction process. Research has shown the the largest amount of humic acids can be obtained from medium to highly decomposed peat bog [81]. By Krumins et al. [82] research, when compared with raised bog peat, fen peat is more decomposed, therefore it has a higher HA content (30-60\%). However, the content of fulvic acid in lowland peat is lower (10-15\%) than in high-moor peat. And the highest content of FA can usually be found in the upper layers of peat of raised bogs. And Sire and Klavins [83] hypothesized that the topmost peat layers are subjected to periodic drying and wetting, which can increase aerobic decomposition and oxidation. As a result, the elemental composition of peat HAs does not regularly change with the depth in the peat layer [83].

Also of particular interest is the study of the effect of drainage on peat soil. Szajdak et al. [84] found that the HAs of undrained peatlands are richer in aromatic structures and therefore can be considered as more humified and mature (hence, more stable) than the HAs of peat bog soils [84].

In order to eliminate mineral present in peat samples Machado et al. [85] washed peat samples by using $0.145 \mathrm{M} \mathrm{HCl}$ for an hour, allowed to settle for $24 \mathrm{~h}$ at $4{ }^{\circ} \mathrm{C}$. In turn, according to Klavins and Purmalis [86], [87], Klavins et al. [88] peat was treated by $0.1 \mathrm{M}$ $\mathrm{HCl}$ solution for an hour. The obtained slurry was allowed to settle and supernant was 
decanted and discarded. Then water was added to the peat mass and slurry was allowed to settle for $30 \mathrm{~min}$. As a result of the addition of $1 \mathrm{M} \mathrm{NaOH}$, the $\mathrm{pH}$ was adjusted to 7 .

In order to eliminate organic impurities in peat samples was considered by Klocking et al. [89], which consisted in the following: the freeze-dried peat sample was extracted with a mixture of methyl acetate and cyclohexane in a Soxhlet extractor, then dried under vacuum.

\subsection{Process parameters influence on the extraction}

Over the decades, the concept of humic- and fulvic- substance alkali extraction from peat has been developed by soil chemists and is summarized.

The main mechanism of obtaining HS was characterized by Krumins et al. [81]. As a result of the treatment of bog peat with alkali, the negatively charged phenolic and carboxyl groups of humic acids were deprotonated and repelled, after which the molecules of humic acid formed into an elongated configuration. When the peat extract was acidified and the $\mathrm{pH}$ was lowered to 1.5 , the hydrophobic part remained in the structure of humic acid, while the hydrophilic part came into contact with the extract. Acidification caused the protonation of functional groups, and the molecules of humic acid formed helical and compact aggregates at the intramolecular and intermolecular levels, as a result of which humic acid precipitated from the solution. The precipitated HA were removed from the solution by filtration and the $\mathrm{pH}$ was adjusted to 7 by washing with distilled water.

In order to study the effect of the type and concentration on the yield of humic acids, Huey et al. [90] isolated HA using 0.1, 0.2, 0.3, 0.4, $0.5 \mathrm{M}$ alkali ( $\mathrm{NaOH}$ and $\mathrm{KOH})$ solutions. After extraction peat samples were centrifuged and supernant was decanted. Solution was acidified to the $\mathrm{pH}$ value 1 and equilibrated at room temperature for $24 \mathrm{~h}$. Then solutions were centrifugated and the supernant containing FA was decanted, but solid phase containing HA was washed by $100 \mathrm{~mL}$ of distilled $\mathrm{H} 2 \mathrm{O}$ to reduce minerals and $\mathrm{Cl}$ - anions. The procedure was repeated 5 times. The washed HA samples were dried in oven at $40{ }^{\circ} \mathrm{C}$ temperature to a constant weight. As shown 4, the higher the concentration of extractant, the higher the yield of HA [90].

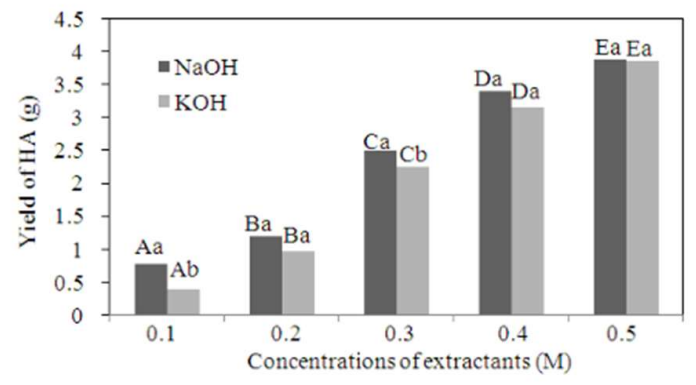

Figure 4. Yield (g) of $\mathrm{HA}$ isolated using different concentrations of $\mathrm{NaOH}$ and $\mathrm{KOH}$ according to Huey et al. [90].

However, $\mathrm{HA}$ isolated with $0.5 \mathrm{M} \mathrm{KOH}$ may contain more foreign substances than $\mathrm{HA}$ isolated with $0.5 \mathrm{M} \mathrm{NaOH}$; therefore, the $\mathrm{HA}$ extraction using $0.5 \mathrm{M} \mathrm{NaOH}$ can be considered more efficient. But the yields of $\mathrm{HA}$ isolated using $\mathrm{NaOH}$ and $\mathrm{KOH}$ did not differ significantly [90]. But Saito and Seckler [91] asserted that a larger amount of HS of higher purity was obtained with $\mathrm{KOH}$ as compared to $\mathrm{NaOH}$. The method was effective but delivered a diluted extract.

Botero et al. [92], Fuentes et al. [93], Zaccone et al. [94] used peat extraction with 0.1 $\mathrm{M} \mathrm{Na}_{4} \mathrm{P}_{2} \mathrm{O}_{7}$ and mixture of $\quad 0.1 \mathrm{M} \mathrm{Na}_{4} \mathrm{P}_{2} \mathrm{O}_{7}$ and $0.1 \mathrm{M} \mathrm{NaOH}$. The results showed that the use of tetrasodium pyrophosphate as an extractant is effective. The results showed that the use of tetrasodium pyrophosphate as an extractant is effective. In the study of Fuentes et al. [93], the yield of fulvic acids was higher than that of humic acids using a mixture of $\mathrm{Na}_{4} \mathrm{P}_{2} \mathrm{O}_{7}$ and $\mathrm{NaOH}$ as an extractant. The literature has been suggesting the use of this 
mixture as extractant, due to the little modifications in the chemical structure of extracted HS. But it is important to understand that there must be control over the amount of added $\mathrm{Na}_{4} \mathrm{P}_{2} \mathrm{O}_{7}$, because excess phosphorus can adversely affect the environment. [92].

In Saito and Seckler [91] research was found that extractants containing hydroxides and sodium carbonates in concentrations of $0.1 \mathrm{M}$ and $0.5 \mathrm{M}$ are effective for removal of HSs from peat soil. It was found to be optimal by using as extractant a $0.5 \mathrm{~N} \mathrm{KOH}$ solution, an extraction time of $4 \mathrm{~h}$ and a peat-to-extractant ratio of 1:20 (mass:volume) at $25-30{ }^{\circ} \mathrm{C}$ under a $\mathrm{N}_{2}$ gas atmosphere with mechanical stirring. Extraction time of several hours is necessary due to the slow depolymerization of complexes with high molecular weight. Alkaline treatment causes contaminants such as salts, silica, clay, structural and protoplasmic components of fresh organic tissues in the HS extract. High temperatures should also be avoided, since they promote the decomposition of amino acids present in the molecular chains of humic acids [91].

As optimum conditions to obtain near homogeneous extract (solid content lower than $0.11 \mathrm{~g} \cdot \mathrm{L}^{-1}$ ), centrifugation at $6,000 \mathrm{n} \cdot \mathrm{min}^{-1}$ for $2 \mathrm{~min}$ was recommended by TrusekHolownia and Ciereszko [95]. In the Botero et al. [92] the extraction of HS by continuous flow and by batch were carried out. And as a result, the continuous flow showed to be efficient, decreasing about 2 hours the extraction time and providing higher yields when compared with the system by batch.

For coagulation of colloidal particles Lodygin et al. [80] added $0.3 \mathrm{M} \mathrm{NaCl}$ to the extract and centrifuged at 10,000 rpm for an hour.

\subsection{HA and FA separation}

Most of the researchers whose work is overlooked in this review precipitated humic acids by acidification with hydrochloric acid to $\mathrm{pH}<2$. Klocking et al. [89] used oxalic acid, Fuentes et al. [93] used sulfuric acid.

\subsubsection{HA fraction purification}

In order to reduce the presence of mineral particles in solid residue Machado et al. [85], Klavins and Purmalis [86], [87], Lodygin et al. [80], Lestari [96], Klavins et al. [88] the solid part after centrifugation was suspended in a mixture of $0.1 \mathrm{M} \mathrm{HCl}$ and $0.3 \mathrm{M} \mathrm{HF}$. This process was repeated until the ash content of HS was reduced to $2 \%$ [86]-[88] or until the ash content of HA is $<1 \%$ [96]. Then the precipitate was washed in deionised water [85] / distilled water [86], [88], [93], [96] until negative $\mathrm{Cl}^{-}$test. The $\mathrm{Cl}^{-}$presence controlled by $\mathrm{AgNO}_{3}$ solution [85], [93], [97]. The HA were dissolved in $0.113 \mathrm{M} \mathrm{NaOH}$ and eluted [85].

According to Lodygin et al. [80], Vasilevich et al. [98], an additional purification of HAs from soluble substances was carried out with dialysis. In the Zaccone et al. [94], dialysis of HA was carried out in a special way, the HA were dialyzed, washed with water at frequent intervals $(6-7 \mathrm{~h})$ in order to remove $\mathrm{Cl}^{-}$until the electrical conductivity of discharged water decreased below $10-2 \mathrm{dS} \cdot \mathrm{m}^{-1}$. All solutions were prepared with high purity water $(18.2 \mathrm{M} \Omega \mathrm{cm})$ and reagents [94].

\subsubsection{FA fraction purification}

By Machado et al. [85] method, the obtained FA solution was acidified with $0.145 \mathrm{M}$ $\mathrm{HCl}$ and eluted a number of times, the FAs were adsorbed and the column washed with dionised water and eluted in $\mathrm{NaOH}$ (to eliminate salt present). In turn Klavins et al. [88] passed the obtained FA solutions through a strong cationite column. According to Fuentes et al. [93], FAs were purified from the fulvic extract by sorption onto a column, washed with deionized water. Finally, FAs were desorbed by adding $0.1 \mathrm{M} \mathrm{NaOH}$. The $\mathrm{pH}$ of the solution was lowered to 2-3 with an acidic cation-exchange resin. Immediately afterward, the resin was separated from the solution by centrifugation. The simplest way to purify FA can be considered the Vasilevich et al. [98] method, in which FA were purified on activated carbon. 
In order to study the content of HA and FA in different fractions of the obtained HSs, Maronese et al. [97] conducted the following experiment: the samples were separated into different apparent molecular sizes fractions by tangential ultrafiltration. Samples of all fractions were freeze-dried for analysis (Table 6).

Table 4. HA and FA content of different AMS of HSP, where FA=total - HA (modified Maroneze et al. [97]).

\begin{tabular}{cccc}
\hline & HS fraction & HA, $\%$ & FA, \% \\
\hline F1 & $<0.45 \mu \mathrm{m}$ & 86 & 14 \\
F2 & $100 \mathrm{kDa}-0.45 \mu \mathrm{m}$ & 93 & 7 \\
F3 & $30-100 \mathrm{kDa}$ & 27 & 73 \\
F4 & $<30 \mathrm{kDa}$ & 12 & 88 \\
\hline
\end{tabular}

According to the data obtained, in the larger fractions, the HA content was higher than in FA, and in the small fractions, on the other hand, the presence of FA was higher than in HA [97]. The basic scheme of obtaining HA and FA is shown in Fig. 5.

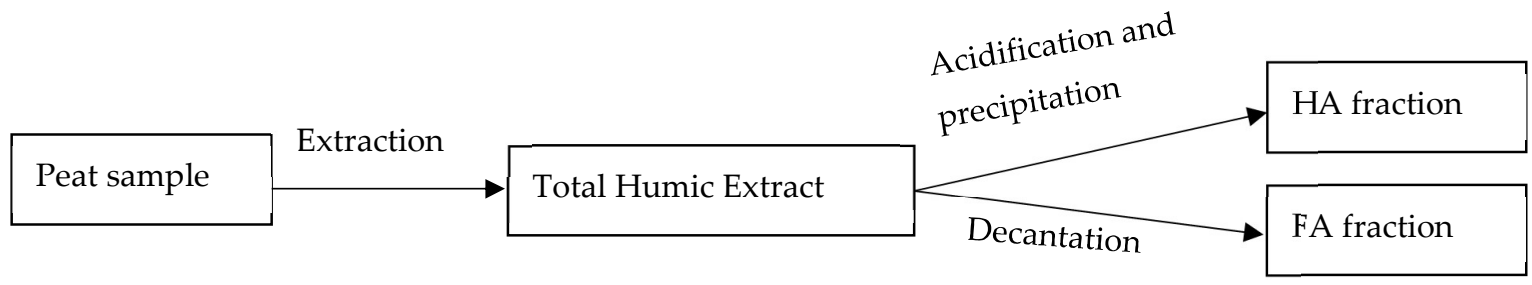

Figure 5. The basic scheme of obtaining HA and FA.

Generalized information on the methods of HS extraction is included in Table 7.

Table 5. Generalized information on the methods of HS extraction.

\begin{tabular}{|c|c|c|c|c|c|c|c|c|}
\hline \multirow[b]{2}{*}{$\begin{array}{l}\text { Layer of } \\
\text { peat soil }\end{array}$} & \multirow[b]{2}{*}{ Sample mass } & \multirow[b]{2}{*}{$\begin{array}{c}\text { Extract- } \\
\text { ant }\end{array}$} & \multirow[b]{2}{*}{$\begin{array}{l}\text { Extraction para- } \\
\text { meters }\end{array}$} & \multirow[b]{2}{*}{$\begin{array}{l}\text { Acidifica- } \\
\text { tion }\end{array}$} & \multirow{2}{*}{$\begin{array}{c}\text { HS sample } \\
\text { drying }\end{array}$} & \multicolumn{2}{|c|}{ EYHS, \% } & \multirow[t]{2}{*}{ Ref. } \\
\hline & & & & & & $\begin{array}{c}\text { EYHA, } \\
\%\end{array}$ & $\begin{array}{c}\mathrm{EY} \\
\%\end{array}$ & \\
\hline $\begin{array}{l}10-190 \\
\mathrm{~cm}\end{array}$ & $\begin{array}{c}\text { Extract- } \\
\text { ant/peat mass } \\
\text { ratio 10:1 }\end{array}$ & $\begin{array}{c}0.1 \mathrm{M} \\
\mathrm{NaOH}\end{array}$ & $\begin{array}{l}\text { Double extrac- } \\
\text { tion, } \\
0.3 \mathrm{M} \mathrm{NaCl} \text { ad- } \\
\text { dition }\end{array}$ & $\begin{array}{c}\mathrm{pH}=1 \\
6 \mathrm{M} \mathrm{HCl}\end{array}$ & $40^{\circ} \mathrm{C}$ & n. d. & n. d. & [80] \\
\hline n. d. & $10 \mathrm{~g}$ & $\begin{array}{c}1 \mathrm{M} \\
\mathrm{NaOH}\end{array}$ & $\begin{array}{c}\text { Total volume: } 2 \\
\text { L (24h) } \\
\mathrm{N}_{2} \text { atm. }\end{array}$ & $\begin{array}{c}\mathrm{pH}=1 \\
6 \mathrm{M} \mathrm{HCl}\end{array}$ & $\begin{array}{l}\text { Freeze dried/ } \\
\text { lyo-phili-zed }\end{array}$ & n. d. & n. d. & [86] \\
\hline & $50 \Omega$ & $1 \mathrm{M}$ & Shak on for $24 \mathrm{~h}$ & $\begin{array}{c}\mathrm{pH}=2 \\
35 \% 11.6 \mathrm{M}\end{array}$ & Airdried & $30-60$ & $10-15$ & {$[82]$} \\
\hline $\begin{array}{l}\text { Raised } \\
\text { bog }\end{array}$ & $00 \mathrm{~g}$ & $\mathrm{KOH}$ & SHakent IOT 2410 & $\begin{array}{c}\mathrm{HCl}(24 \mathrm{~h} \text { at } \\
\left.\text { troom, }{ }^{\circ} \mathrm{C}\right)\end{array}$ & An uned & $20-30$ & $10-20$ & {$[02]$} \\
\hline $\begin{array}{c}0-25 \\
25-50 \\
50-75 \\
75-100 \\
\mathrm{~cm}\end{array}$ & $\begin{array}{c}\text { Extract- } \\
\text { ant/peat ratio } \\
(\mathrm{v} / \mathrm{v}) 5: 1\end{array}$ & $\begin{array}{c}0.1 \mathrm{M} \\
\mathrm{NaOH}\end{array}$ & $\begin{array}{c}\text { Shaken for } 4 \mathrm{~h} \\
\text { pH=7 } \\
\mathrm{N}_{2} \text { atmosphere } \\
\text { Stored overnight }\end{array}$ & $\begin{array}{c}\mathrm{pH}=1.3 \\
6 \mathrm{M} \mathrm{HCl} \\
(24 \mathrm{~h} \text { at } \\
\left.\text { troom, }^{\circ} \mathrm{C}\right)\end{array}$ & $\begin{array}{l}\text { Freeze dried, } \\
\text { stored in a } \\
\text { vacuum desic- } \\
\text { cator over } \mathrm{P}_{2} \mathrm{O}_{5}\end{array}$ & n. d. & n. d. & [84] \\
\hline $0-10 \mathrm{~cm}$ & $5 \mathrm{~g}$ & $\begin{array}{c}0.133 \mathrm{M} \\
\mathrm{NaOH}\end{array}$ & $\begin{array}{c}24 \mathrm{~h} \text { at } 4{ }^{\circ} \mathrm{C} \\
\mathrm{N}_{2} \text { atm. }\end{array}$ & $\begin{array}{l}\mathrm{pH}=1.2 \\
6 \mathrm{M} \mathrm{HCl}\end{array}$ & Air dried & n. d. & n. d. & [85] \\
\hline
\end{tabular}


n. d.

n. d.

n. d.

$1 \mathrm{~kg}$

$0.1 \mathrm{M}$
$\mathrm{NaOH}$

$0-15 \mathrm{~cm}$

n. d.

n. d.

n. d.

$$
\text { 0.5-0.6 g }
$$

Extractant/peat ratio 6:1

n. d.

$1 \mathrm{~kg}$

$0.1 \mathrm{M}$

$0.2 \mathrm{M}$

$0.3 \mathrm{M}$

$0.4 \mathrm{M}$

$0.5 \mathrm{M}$

$\mathrm{NaOH}$

$0.1 \mathrm{M}$

$0.2 \mathrm{M}$

$0.3 \mathrm{M}$

$0.4 \mathrm{M}$

$0.5 \mathrm{M}$

$\mathrm{KOH}$

$0.1 \mathrm{M}$

$\mathrm{NaOH}$

$0.1 \mathrm{M}$

$\mathrm{KOH}$

$0.1 \mathrm{M}$

$0.1 \mathrm{M}$

$\mathrm{NaOH}$

$0.1 \mathrm{M}$

$\mathrm{KOH}$

$0.1 \mathrm{M}$

$0.1 \mathrm{M}$

$\mathrm{Na}_{4} \mathrm{P}_{2} \mathrm{O}_{7}$

$+0.1 \mathrm{M}$

$\mathrm{NaOH}$

$0.1 \mathrm{M}$

$\mathrm{NaOH}$

$0.5 \mathrm{M}$

$\mathrm{NaOH}$

$0.1 \mathrm{M}$
Total volume: 10

$$
\text { L (24h) }
$$
$\mathrm{N}_{2} \mathrm{~atm}$.

$\mathrm{pH}=1$

$6 \mathrm{M} \mathrm{HCl} \quad$ Freeze dried

n. d.

n. d.

[88]

2h under mild conditions

$\begin{array}{cc}\mathrm{NaOH} & \text { conditions } \\ \mathrm{KOH} & \left(30^{\circ} \mathrm{C},\right. \\ & \mathrm{pH} 9)\end{array}$

$\mathrm{pH}=1.5$ Oxalic acid

Freeze dried

n. d.

n. d.

[89]

$$
\begin{aligned}
& 24 \mathrm{~h} \\
& 180 \text { rpm (me- } \\
& \text { chanical stir- } \\
& \text { ring) }
\end{aligned}
$$
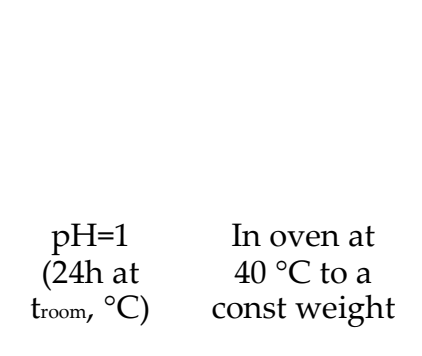

$$
8
$$

12

25

n. d.

39

n. d.

n. d.

Air dried

25.3- $\quad 1.37-$

$35.5 \quad 2.85$

[91]

$\mathrm{Na}_{4} \mathrm{P}_{2} \mathrm{O}_{7}$

troom $\left.=(25 \pm 2)^{\circ} \mathrm{C}\right)$

Conti-nuous

flow $(2 \mathrm{~h})$

$\mathrm{Na}_{4} \mathrm{P}_{2} \mathrm{O}_{7}$

Batch Extractant/peat ratio

(v/m) 10:1, stir-

ring for $4 \mathrm{~h}$ under $\mathrm{N}_{2}$ atm.

$\mathrm{HCl}$ with air exchange

$\mathrm{pH}=1-2$

Shaking for an hour at troom, ${ }^{\circ} \mathrm{C}$

$95 \% \mathrm{H}_{2} \mathrm{SO}_{4}$

(8h)

12 6.4

Air dried

[93]

Mechanical shaking in dark place for $24 \mathrm{~h}$ under $\mathrm{N}_{2}$ gas

$\mathrm{pH}=2$ $5 \mathrm{M} \mathrm{HCl}$

5.4 3.6

$\mathrm{Na}_{4} \mathrm{P}_{2} \mathrm{O}_{7}$
$0.5 \mathrm{M}$

Stirring for $12 \mathrm{~h}$

$\mathrm{N}_{2}$ atm.

$\mathrm{pH}=1$

$\mathrm{HCl}$

(24h)

7.57-

22.81

Freeze dried $\quad 0.28-$
1.97

n. d.

[94]

$\mathrm{NaOH}+$ 


\begin{tabular}{|c|c|c|c|c|c|c|c|c|}
\hline $40 \mathrm{~cm}$ & $50 \mathrm{~g}$ & $\begin{array}{l}0.5 \mathrm{M} \\
\mathrm{KOH}\end{array}$ & $\begin{array}{l}\text { Stirred for } 4 \mathrm{~h} \text { at } \\
\text { troom, }{ }^{\circ} \mathrm{C} \text {. Al- } \\
\text { lowed to settle } \\
\text { for } 48 \mathrm{~h} .\end{array}$ & $\begin{array}{c}\mathrm{pH}=6 \\
0.1 \mathrm{M} \mathrm{HCl}\end{array}$ & Air dried & $12-93$ & $7-88$ & [97] \\
\hline $\begin{array}{c}0-10 \\
10-20 \\
20-40 \\
40-60 \\
60-80 \\
80-100 \\
100-150 \\
150-175 \\
175-200 \\
\mathrm{~cm}\end{array}$ & n. d. & $\begin{array}{c}0.1 \mathrm{M} \\
\mathrm{NaOH}\end{array}$ & $\begin{array}{l}\text { Double extrac- } \\
\text { tion }\end{array}$ & n. d. & $\begin{array}{l}\text { In the } \\
\text { beaker at } \\
35^{\circ} \mathrm{C}\end{array}$ & $\begin{array}{c}16.6 \\
24.8 \\
21.8 \\
26.9 \\
11.2 \\
3.9 \\
2.4 \\
4.1 \\
3.4\end{array}$ & n. d. & [98] \\
\hline $150 \mathrm{~cm}$ & $\begin{array}{l}10 \mathrm{~g} \\
\text { Extract/ peat } \\
\text { ratio } 10: 1\end{array}$ & $\begin{array}{c}0.1 \mathrm{M} \\
\mathrm{NaOH}\end{array}$ & $\begin{array}{c}\text { Shaking for } 12 \mathrm{~h} \text {, } \\
\text { allowed to settle } \\
\text { overnight }\end{array}$ & $\begin{array}{c}\mathrm{pH}=1 \\
6 \mathrm{M} \mathrm{HCl} \\
(16 \mathrm{~h})\end{array}$ & $\begin{array}{c}\text { Dried in an } \\
\text { oven at } \\
25^{\circ} \mathrm{C}\end{array}$ & n. d. & n. d. & [99] \\
\hline $30-40 \mathrm{~cm}$ & $\begin{array}{l}\mathrm{NaOH} / \\
\text { peat ratio } \\
(\mathrm{w}: \mathrm{v}) 40: 1\end{array}$ & $\begin{array}{c}0.1 \mathrm{M} \\
\mathrm{NaOH}\end{array}$ & $4 \mathrm{~h}$ & $\mathrm{pH}=2.0-2.2$ & $\begin{array}{l}\text { Dried at troom } \\
\text { for } 48 \mathrm{~h}, \\
1058^{\circ} \mathrm{C} \text { for } \\
\text { 6h. Stored in } \\
\text { dessicator. }\end{array}$ & $\begin{array}{c}0.43- \\
1.54\end{array}$ & n. d. & $\begin{array}{c}{[100} \\
]\end{array}$ \\
\hline
\end{tabular}

The most optimal and effective way to extract HS from peat can be considered: extraction of peat samples with a solution of $0.5 \mathrm{M} \mathrm{NaOH}$ for 24 hours with constant mechanical stirring at room temperature $\left(25^{\circ} \mathrm{C}\right)$ and acidification of the resulting suspension with a solution of $6 \mathrm{M} \mathrm{HCl}$ until a $\mathrm{pH}$ value of 1-2 is reached, allowed to settle overnight. The fulvic acid supernant can be further purified through the column. The sludge containing humic acids can be treated with an $\mathrm{HCl}+\mathrm{HF}$ mixture to reduce the mineral content and washed with distilled water to a negative chlorine ion test.

\subsection{Industrial use of $H S$}

The potassium and sodium humates are used in a range of industrial manufacturing processes - from cement and concrete to drilling fluids, paper, cardboard, natural pigments and water recycling.

\subsubsection{HS in civil engeenering}

Peat humic acids can be used as liquefiers in concrete. They diminish use of concrete an improve its overall physicomechanical properties. The humic acids have a potential as a distinct density control additive in cement or concrete. Because of their hydrophobic properties, using humic acids outcomes in very little water uptake. This leads to either a minimum use and an improved workability of the cement or to an increase in cement stability whereas the amount of used cement remains the same. The humic acids help to diminish water surface tension, resulting in better utilization of solid particles in concrete. Use of humic acids also can direct to a complete fine separation of the cement, thereby the friction between solid particles can be limited, resulting in a better versatility and workability of the concrete [101], [102].

The humic acids have been traditionally used in ceramics as liquefier and dispersant agents. They can be used as liquefiers for glazes and to liquefying and diluting certain ceramic masses. These ceramic masses, that are prepared in fluid state need liquefier agents in order to optimize the rheological behaviour of the produced mud [103]. Consequently, peat humic acids can control the viscosity, rheology and $\mathrm{pH}$-value of the ceramic material and improve the crack-resistance and absorption time.

The humic acids can be used in modifying asphalt-based products, for example, roofing compounds, mastics, sealants, coatings, etc. Because of their dispersant characteristics, 
humic acids have the potential of enhancing the loading of inert solids. They also have potential as crack-resistant agents, flow control additives, sag resistant agents, spray modifiers, adhesion modifiers, and as agents to control penetration and evaporation of asphalt solvents. Humic acids can assist in stabilization of certain types of asphalt based undercoating and soundproofing compounds, they also can aid in improving the aging characteristics and the thermal stability of asphalt-based systems.

\subsubsection{HS as sorbents}

The humic acids are a rather high surface area material, they are organophilic and exhibit certain types of reactive sites such as phenolic hydroxyl groups and carboxylic acid groups. They have the ability to adsorb, absorb and selectively extract various organic materials, as well as certain inorganic compounds. Therefore, humic acids can be used in special filter media, selective extractants and chromatographic substances. Peat humic acids can be used for removing trace amounts of nonaqueous liquids, for instance, oils from aqueous streams. They can also be utilized in the removal of trace contaminants from aqueous streams [104].

\subsubsection{HS in energy accumulators and batteries}

Peat humic acids can be used in the energy industry as expanders in lead accumulators. The humic acids are surface active materials, hence they can control the size and morphology of $\mathrm{Pb}$ and lead sulphate compounds through the charging and discharging cycles. The humic acids are producing an increase in the charge potential and the discharging capacity of lead accumulators; they are also reducing self-discharge of the battery and in that way they are prolonging battery life [105].

\subsubsection{HS in drilling fluids, controlled release agents and defoamers}

Peat humic acids are organic carboxylic acids of complex aromatic and phenolic molecular structure. The decarboxylation of humic acid groups by hydrolysis in alkaline muds is a major source of carbonate and bicarbonate anions in water muds. The humic acids can be used as a fluid loss additive in oil base and water base drilling fluids. The humic acid in general have three functions when used in drilling fluids - it reduces the viscosity and gel strength; humic acid thinners the drilling fluid and controls the deflocculation, dispersation and rheological properties; and regulates fluid loss and emulsion. The humic acid additives are often used as shale inhibiting agents for freshwater drilling fluids and function as viscosity reducers and water-loss reducers [106].

Peat humic acids also can be used in controlled release applications, due to their high, porous and hydrophobic surface area, where it is important to adsorb, absorb and release products at controlled rates. The humic acids also can be used as solid or liquid defoamers, because of their high surface area and hydrophobic nature.

\subsubsection{HS in foundries and green sand systems}

The humic acids can be used as foundry sand additives because of their dispersant properties and binding features both in oil and water-based foundry sand. The humic acids can block electrostatic interaction, hence they can make the clay in sand systems unwettable. Furthermore, peat humic acids can reduce clay viscosity, improve muller efficiency and increase mould permeability. They also absorb and retain water and improve foundry environment. Use of humic acids in foundries and green sand systems as an additive can boost the flowability and clay efficiency and therefore initiate reduced use of clay in the sand system, in the long run saving costs considerably [107].

\subsubsection{HS in chemical industry}

Paper and cardboard

Peat humic acids can be used for paper colouring, which, at the same time, eliminates the penetration of toxic substances through the coloured paper into the wastewater. The humic acids can be used as special additives for certain types of dark coloured papers, particularly those requiring the use of oils, waxes, resins, etc. Peat humic acids can also be 
applied in adjusting water-proofing agents and barrier coatings used in paper products. They can be regarded as black tinting agents an special fillers, and can be used where it is important to prevent penetration of nonaqueous liquids during paper production.

$H S$ as grease and lubricants

Peat humic acids because of their organophilic nature and stability in high temperatures can be used as additives for modifying the gel structure and other properties of soap, organoclay based greases and lubricants. Moreover, through use of humic acids, a higher purity and finer grind of required product can be attained.

HS as natural pigments, paints, industrial coatings and printing inks

The humic acids can be used to manufacture the Van Dyke brown colour pigment. It was first used in European painting in the 17th century and is still in use today. However, the oil consumption using this pigment is large, because of high humic acid absorption capacity. Moreover, the humic acids can be used as black tinting agents, special pigments and rheological control additives in oil-based paints, industrial coatings, varnishes and shellacs. They can be used for colouring wood, leather and carpets. Peat humic acids can be applied for modifying the rheological properties of black or dark coloured printing inks. They exhibit dispersant properties in certain types of solvent-based systems. The humic acids can be used as colloidal tinting pigments because of their black colour. An important property of humic acids is their ability to limit penetration of certain oils into porous substrates and this is especially applicable for certain types of ink formulations for paper and ribbon [108].

HS in rubber production

Peat humic acids can be used in the compounding and processing of rubber. Some of the most efficient uses of peat humic acids are as fillers, extenders, tinting compounds, property modifiers, antioxidants, pigment dispersants. Humic acids aid to rubber elasticity, resistance, anti-cracking, crazing and aging [109].

\subsection{HS in agriculture}

The HS occur naturally in most natural soils, but they are intensely absent in arable lands worldwide. In there, fen peat HS applications can be used as soil improvers. Amongst the most essential effects of HS applications on soils are an increased plant growth and yields, less consumption of fertilizer. This all together results in an increase in fertilizer efficiency, in lower overall costs and better resistance against microorganisms and pathogens, and an increased soil quality and fertility [110].

\subsubsection{HS in horticulture}

Crop production in controlled environments, such as greenhouses, involves adjustable microclimate, where crop cultivation is possible as required in order to gain high yield and good quality in a short time. Therefore, the optimization and adjustment of environmental parameters, for example, the temperature, light, carbon dioxide and relative humidity, are entailed, alongside with optimized soil physical, chemical and biochemical properties. The application of HS-based products can improve these soil parameters by increasing its porosity and cation exchange capacity, which in turn can raise the biological activity within the soil and aeration conditions that in the end result in better water and nutrient storage, improved root development, optimized $\mathrm{pH}$ values, reduced salinity, resistance against diseases and many other valuable properties. The HS-based applications can significantly stimulate plant growth and thus are permitting to acquire higher yields and quality in practically all horticultural crops [110], [111].

\subsubsection{HS in hydroponic systems}

Hydroponic plant growing takes place in enclosed and controlled settings and hence it is possible to cultivate crops with a better use of fertilizer applications and a minimum of waste. The application of HS on these crops can notably boost the nutrient availability to plants. If nutrients are readily available to plants, then the intensity of photosynthesis processes can be amplified because of the chelation reactions. Therefore, plants can 
produce and store more carbohydrates and as a result, a well-developed root system with a larger volume of root hairs and feeder roots can aid the plant to take in other compulsory nutrients in the fertilizer solution to accelerate cell division more quickly. The HS continue stimulating plant growth through its full development cycle, leading to earlier and better yield [112], [113].

\subsubsection{HS in pasture management}

The application of HS onto grasslands can promote photosynthesis, plant respiration, nucleic acid synthesis and ion uptake [114]. Therefore, HS can be used for plant cultures that are planned to be used for hay. Peat HS can impact the production of ribonucleic acid, which is essential for most biochemical processes in plant cells. Peat HS can also stimulate enzyme reactions, such as enhancing the presence of various antioxidants in plant leaves. The HS initiate production of antioxidants and enhance photosynthetic activity, resulting in greater plant tolerance against abiotic and biotic stresses, including infection. Therefore, using HS that reduce the impact of environmental stresses could also be a valuable component of an integrated pest management strategy in plant cultures [115].

\subsubsection{HS in viticulture}

The HS applications, such as humates are commonly utilised in the viticulture. It is done to improve soil structure and biological activity and to reduce possible risks for diseases. The accumulation of HS in soils progressively affects soil water holding capacity, temperature and $\mathrm{pH}$ range, improving nutrient availability and health maintenance against soil-borne diseases [116]. At the same time, humic acid-containing foliar sprays wield such positive effects as increased chlorophyll content, lowered acidity and increase in berry size in grapes [117].

\subsubsection{HS in seed treatment}

Peat HS can be applied to plant seeds in order to protect them from microbial and fungal impact, they can enable metabolic and enzymatic processes at embryonic level [118]. In seed treatment, the humic acids usually are introduced in a vastly concentrated form. Initially, humic acids are brought directly into contact with seeds and are then involved once more at a later stage in the outer layer of the seed coating. The humic acids come into direct contact with seeds, before they are coated with several nutritious layers and seed grains are subjected to thorough treatment with a highly concentrated humic acid solution. The treatment with humic acids alters seed cell membrane, boosts metabolism activities and increases the seed germination rate. The application of humic acids increases seed nutrient uptake capacity and promotes the growth of the seed. Furthermore, humic acids raise the sugar and vitamin content in seeds. Ordinarily, seed treatment with humic acids improves the nutrition uptake; increases germination and establishment, promotes root development; and reduces seed susceptibility to pests and diseases [119].

\subsubsection{HS in environmental remediation}

Peat HS have high potential in environmental remediation. They can interact with ecotoxicans and are known to form stable complexes with heavy metals. Humic acids also act as electron shuttles, facilitate transition metal reduction-oxidation reactions, and affect the interphase of contaminant distribution [120].

\subsubsection{HS in erosion control}

The humic acid-containing soil conditioners can advance soil physical and biological properties and therefore they can be used for soil erosion control. Peat humic acid-based soil conditioners can adjust the soil structure and nutrient content to enhance plant development and growth. Peat humic acid applications can work as growth enhancers and improve plant metabolism, they can increase chlorophyll efficiency and production, rise 
antioxidant content, improve nutrient availability and boost water-holding capacity of the soil. The humic acids can enhance the root system and plant development. Furthermore, humic acids can improve the ability of soil colloids to combine by increasing the cohesive forces of soil particles. The humic acids bind nutrients and heavy metals and amplify soil cation exchange capacity, thereby increasing the sites in which nutrients and metals can be bound. Peat humic acids generally promote good soil tilth and adds the amount organic matter, microbial activity and microbial count in the soil [121]. The humic acids also provide a high level of available carbon, which acts as a food source for microorganisms; trace minerals in a colloidal suspension that are readily available for plant uptake and development; organic acids that can enhance nutrient uptake; and aid in early root-zone development. The humic acids can be effectively used for the recultivation of steep slopes, highway banks and roadsides, for slope stabilizing and embankment, greening of mining fields, refuse dumps, construction sites and landfills, maintenance of parks, sports grounds, etc.

The humic acids are forming complexes with polyvalent cations and this feature can be used in soils with excess salination. Peat humic acid applications can fix soil anions and cations and exclude them from plant roots, thus reducing soil salinity and improving growth conditions [122].

\subsubsection{HS in soil decontamination}

The industrial development and manufacturing have resulted in wide scale soil ecological degradation and contamination with hazardous organic and inorganic chemicals. Many soils worldwide have been contaminated with petroleum residues, solvents, pesticides, herbicides, wood preservatives, etc. hydrocarbons. Peat humic acids and other applications that are based on HS can be used in bioremediation to reduce soil contamination [123]. Soil biological treatment with humic acids is comparatively lower cost than conventional methods and can be effectively conducted in-situ and therefore expels the need to detoxify or dispose of contaminated solvents or other cleansing materials. Peat humic acids are not toxic and biodegrade slowly. The humic acids have low oxygen demand and have high fixation and adsorption properties for most xenobiotics in soil [124]. Additionally, dissolved humic acids can be used for improving dense nonaqueous-phase liquid mobilization and solubilization processes in soil.

\subsubsection{HS in wastewater treatment}

Peat humic acid applications can be used for subtracting toxic metals and their ions from household wastewaters. For instance, the humic acids can be applied as an accessory in dissolved air flotation cells to assist in the removal of grease, oil, liquid organics and suspended matter [125]. The humic acids are regarded as coagulant aid to be used in combining with water-soluble polymeric flocculants for removal of soluble organics [126]. They can also be used as fluid loss chemicals in certain types of organic liquids, for instance, to prevent leak from lagoons or pit containment areas [127]. The highest effect can be observed in the removal of $\mathrm{Pb}, \mathrm{Hg}, \mathrm{Cd}, \mathrm{Cu}, \mathrm{Zn}, \mathrm{Ni}$ and $\mathrm{Cr}$, Al. Peat humic acids have high cation exchange capacity and electron exchange capacity, that allows them to adsorb lipophilic substances and form hardly soluble complexes with polyvalent cations and heavy metals. The cation exchange capacity of humic acids (with Ca ion at $\mathrm{pH} 7.0$ ) tend to increase with increasing humification degree ( 350 to 850 me per $100 \mathrm{~g}$ of peat).

\subsection{HS in medicine}

Peat humic acids can change enzyme activity, for instance, in the skin. The humic acids are traditionally used in the pharmacology, in the preparation of bath salts and mud baths. When produced in a mixture with certain preservatives, products containing humic acids can be applied for the treatment of rheumatic and gynaecological diseases, they also have a potential in cancer treatment [128]. 


\subsubsection{HS in the immobilization of enzymes}

The humic acids can be used for the immobilization of certain types of enzymes, because of their hydrophobic and reactive surface. Peat humic acids have noteworthy antiviral, anti-inflammatory, hormonal stimulating effect on living organisms, in addition to their profibrinolytic and heavy metal binding properties [128], [129]. The humic acids can change the activity of various enzymes, hence they can be used in bath salt and face mask production.

\subsubsection{HS in antiviral drugs}

The humic acids in a mixture with additional preservatives can be used against coxsackie A 9, influenza A, herpes simplex and other viruses. Some studies have confirmed the ability of humic acids to supress AIDS pathogens, type 1 and type 2 of human immunodeficiency virus, cytomegalovirus and bovine smallpox virus [129].

\subsubsection{HS in anti-inflammatory drugs and infection treatment}

Chemical and biochemical properties of humic acids can be used to treat certain inflammations and infections. Peat humic acids can bind thrombin, which is known for causing thrombosis. Therefore, the humic acids can be used to stimulate blood flow, which in turn promotes faster wound healing. The humic acids can be applied to efficiently cure the rheumatoid arthritis, chronic and sub-chronic inflammations of genitals, periodontitis, dermatitis, eczema, burns, bedsores, inflamed sores and other wounds. The humic acids also have a pronounced profibrinolytic activity in occasions of tubal inflammation [129] [79]. Humic acid therapy can be used afterwards a surgery to prevent secondary adhesion and blockage of the fallopian tubes. Using humic acid treatment, proteins that cause blood to clot are naturally broken down into soluble fibrin degradation products, hence preventing the formation of blood clots and promoting wound healing.

\subsection{HS in veterinary}

The HS and humic acids in particular are the key components in animal feed and housing. HS when used as animal feed, supplements and stable beddings can prevent certain diseases and reduce the need for remedies as they absorb toxins and stenches [Error! Reference source not found.,Error! Reference source not found.].

\subsubsection{HS in animal breeding}

The humic acids can be efficiently used as an additive in animal feed. Studies conducted worldwide have shown positive results concerning the use of humic acids as an organic feed ingredient. Data show a boost in the liveweight of animals; an improved growth rate; an increased feed intake and food conversion ratio; and much stronger resistance against diseases. The humic acids improve immune function and reduce the incidence of enteric disease and diarrhoea. The use of humic acids in animal feed aids a number of advantages for animal health and growth. Peat humic acids can inhibit pathogenic bacterial growth and growth of moulds, hence decreasing levels of mycotoxins. They can improve protein digestion and calcium and trace element utilisation. The humic acids can improve gut health, nutrient absorption, nutritional status and immune response in animals. The humic acids also can advance diet digestibility through the maintenance of optimum $\mathrm{pH}$ within the gut, resulting in lower levels of nitrogen excretion and less odour. the humic acids by improving digestibility and food utilisation, can improve gastric and intestinal conditions. Replacing antibiotics with humic acids as an alternative growth promoter in animal feed does not cause any loss in the animal performance. On the contrary, performance factors of animals are considerably improved. Tests have shown that the use of humic acids as animal feed supplement leads to an increased milk production and better butterfat percentage in dairy cows. Using humic acids also resulted in an improved feed efficiency, decreased feed costs, lessened fly population and reduced costs for insect control. Furthermore, the weaning weights were considerably increased and faster weight 
gains were observed in dairy cows, but concerns with scours greatly decreased when humic acids were used [77].

\subsection{HS in aquaculture}

The humic acid-based products are often used to optimize the $\mathrm{pH}$ of soil or water. Use of humic acid applications in aquaculture can result in offspring survival rate rise if eggs and larvae undergo prophylactic treatment. Humic acids can also be used to suppress secondary infections and to increase the vitality of the fish by multiple stress resistance; they also improve growth and feed conversation rate; detoxication of harmful heavy metals and other toxins [130]. The medical treatment of these secondary infections often is difficult since only few substances are permitted for use in aquaculture and the treatment with chemicals frequently is associated with additional stress. The lack of therapeutic and antiparasitic substances against pathogens causes an urgent demand for constitutional, natural and ecological alternatives in aquacultures and fish breeding and humic acids can function in this regard.

\section{Biocomposites from peat}

Peat is an accumulation of partially decayed vegetation or organic matter. For many people peat is associated with fertilizers and fuel. Peat can be used in water filtration and is sometimes utilized for the treatment of urban runoff, wastewater, and septic tank effluent, but new material source is relatively new way for peat use. Peat has potential to be used as biomaterial for various applications. The advantages of products containing peat fibre are their biological origin, low cost, water resistance, impact strength, excellent fire endurance characteristics and biodegradability.

Composite building materials, which can be locally developed with available peat soil, have great potential of application in the construction industry. Blocks and bricks made from local peat soil can be improved to produce masonry units with strengths, high enough to meet building standards. Researchers from Malaya used Peat soil to replace part of the Siliceous sand in construction blocks. The main goal was to achieve a cheaper alternative for available lightweight materials. By replacing $15 \%$ corresponding siliceous sand weight by peat (37\% block volume replacement) the $30 \%$ of block weight reduction was obtained. The compressive strength reduced by $87 \%$, but still fulfilled with the requirement of ASTM C 129 for the non-load bearing masonry units, where the minimum value is 3.50 MPa [131], [132].

Peat is considered a problematic type of soil due to its high compressibility, high moisture content, high organic matter and low shear strength. As a form of stabilization, it is suggested to combine palm oil fuel ash (POFA) with peat. The POFA-peat composites showed an increase of 4 times the untreated peat value. Also, CBR values for these composites increased from 31 to 42 fold, in comparison with untreated peat [133].

Therefore, the usage of waste tyres is seen as a potential replacement additive that can reinforce peat compared to other ground treatments such as cement or coarse aggregates. compaction and unconfined compression strength characteristics of peat when treated with 5, 10, and $15 \%$ waste tyre granules was investigated. Waste tyre granules replace the air voids in peat which results in a $13 \%$ higher density after compaction when treated with $15 \%$ waste tire granules. The unconfined compressive strength test results show that higher percentage of waste tire added in peat results in higher undrained cohesion. Peat sample, which contains $15 \%$ waste tire granules, shows the 9 times more unconfined compressive strength than natural peat [134].

Devulcanised crumb rubber tyres can also be used with peat to make bio-based composite can be used as an oil spill adsorbent. Homogenised peat used as a natural bio-based binder. Devulcanised crumb rubber was used as a porous substrate. Cenospheres can be added to reduce shrinkage and add floatability. Small amount of CS added (5 wt \%) leads to significant decay of apparent density from 1.20 to $0.85 \mathrm{~g} \cdot \mathrm{m}-3$ [135]. An increase of the 
CDR in the block shaped composites leads to a significant decrease of compression strength, in this study by $97 \%$ [136].

Researchers form Tartu, Estonia developed a novel peat composite construction material suitable for three-dimensional printing of entire house boxes. Peat was used as filler to achieve excellent thermal properties. The material was characterized by measuring its thermal resistance $\left(<0.08 \mathrm{~W} \cdot \mathrm{m}^{-1} \cdot \mathrm{K}^{-1}\right)$. Materials compressive strength was $1.2 \mathrm{MPa}$ and bending strengths $0.36 \mathrm{~N} \cdot \mathrm{mm}^{-2}$. However, peat has inhibitory effect on the hardening process of fly ash mortar, but it can be curbed by inducing oxidative condensation of humic matter in highly alkaline medium [137].

It can be concluded that the peat material as opposed to peat-sand mixtures conduct less heat and thereby provides better temperature insulation, which can ensure an appropriate and stable temperature for methanotrophic bacteria within the bio cover, an especially important factor for cold climates when the atmospheric temperature is low.

In this context, a comprehensive assessment and comparison of compaction and consolidation behaviors, and hydraulic and thermal conductivities of peat-based materials, i.e. peat and peat-sand mixtures with a mix ratio of 1:3, 1:1, and 3:1, respectively, for bio covers are made. The maximum dry density and compactability decrease with increasing sand content.

Pure peat has the largest secondary settlement among the studied materials (peatsand mixtures) which results in higher potential of failure of the pure peat-based bio covers due to the development of cracks or changes in the pore structure. However, this can be mitigated by increasing the sand content.

The thermal conductivity increases with increasing bulk density, and moisture and sand contents. However, the effect of the variation in bulk density on thermal conductivity is considerably less than that of the moisture content variation. It is found that pure peat materials can provide better temperature insulation and consequently a more stable temperature within bio covers than the peate sand bio cover materials due to their low thermal conductivity which is particularly important in cold climates [138].

Heat insulating materials from peat composties with quicklime also have some potential to replace traditional materials. Obtained materials have desired thermal conductivity $\left(0.041 \mathrm{~W} \cdot \mathrm{m}^{-1} \cdot \mathrm{K}^{-1}\right)$, low density and low toxicity index. Increasing the peat content from 42 to $85 \%$ and decreasing the quicklime content saw thermal conductivity decreased by $51 \%$ [139].

Peat-wood composite materials compare well with the conventional heat-insulating materials. These materials can be produced by using explosive autohydrolysis method without using synthetic binders. Samples produced by the EAH method from uppermoor peat and peat with addition of pine wood (1:1 by mass) showed thermal conductivity coefficient of $0.044 \mathrm{~W} \cdot \mathrm{m}^{-1} \cdot \mathrm{K}^{-1}$. These materials also have very good bending strength. Taking that into account we can conclude that by using this material, we potentially can decrease the usage of heat insulating materials [140].

To investigate the influence brought by peat soil incorporation to the mortar, peat soil was added to replace river sand at a ratio of 3, 6 and $10 \%$ by weight. Water adsorption increased by $1.1 \%$ in sample with $10 \%$ of peat soil. Thermal conductivity decreased by $45 \%$ in sample with $5 \%$ of peat soil. Most of the samples that consist up to $5 \%$ of peat soil and $30 \%$ of EM able to achieve higher compressive strength than the design strength of $7 \mathrm{MPa}$ at 28-days with the range of 16.48 $\mathrm{MPa}-37.81 \mathrm{MPa}$ [141].

Knowing the negative impact of plastic materials from agriculture sources on the environmental pollution, some of research activities carried on the utilization of secondary cellulose fibers (from recovered papers and boards) and other lignocellulosic materials on obtaining of sustainable composite materials [142].

Among biodegradable goods, disposable plant pots made from peat or from a mixture of peat and wood fiber are most widely used. They can be either embedded into soil together with plants or digested. However, the peat plant pots have some drawbacks. They are mechanically unstable and have a high permeability to water vapor [143]. 
The tests were developed on a pilot plant designed to obtain the pots from a mixture of secondary cellulose fibers, red peat, and other additives. These materials were characterized in terms of biodegradability and growth and development of tomatoes and lettuce seedlings.

Based on the laboratory tests performed on the choice of the ratio between fibrous components, a value of 70/30 peat/secondary cellulose fiber ratio was identified as optimal. A content over $80 \%$ peat has as a result decreased the dewatering rate as well as the dry and wet strength of nutritive biodegradable pots [142].

Hemp and peat fibres were used in order to produce effective ecological thermal insulating material. Tests were carried out using short dishevelled hemp and chopped peat fibres. Macro- and microstructures of composites as well as hemp and peat fibres have shown that activated peat allows getting ecological binder for insulating materials. Fibred peat mass was stirred in the water. Activation of peat in the water was used to obtain peat binder.

Composite was formed from natural fibres (hemp and peat). Hemp-peat fibres composite specimen was produced with hemp and peat fibres having a mass ration of 1:1.

Thermal conductivity tests of the specimens were carried out in accordance with EN 12667 and EN 12939 requirements. Thermal conductivity values of specimens from hemp fibres is approximated from $0.0475 \mathrm{~W} \cdot \mathrm{m}^{-1} \cdot \mathrm{K}^{-1}$ to $0.0430 \mathrm{~W} \cdot \mathrm{m}^{-1} \cdot \mathrm{K}^{-1}$, when the density ranges $40.4 \mathrm{~kg} \cdot \mathrm{m}^{-3}$ to $67.3 \mathrm{~kg} \cdot \mathrm{m}^{-3}$, respectively. Thermal conductivity values of specimens From peat fibres is approximated from $0.0440 \mathrm{~W} \cdot \mathrm{m}^{-1} \cdot \mathrm{K}^{-1}$ to $0.0379 \mathrm{~W} \cdot \mathrm{m}^{-1} \cdot \mathrm{K}^{-1}$, when the density ranges from $41.2 \mathrm{~kg} \cdot \mathrm{m}^{-3}$ to $68.2 \mathrm{~kg} \cdot \mathrm{m}^{-3}$. Produced composite from hemp and peat fibres had a density varying from $173 \mathrm{~kg} \cdot \mathrm{m}^{-3}$ to $186 \mathrm{~kg} \cdot \mathrm{m}^{-3}$ and thermal conductivity ranging from $0.0436 \mathrm{~W} \cdot \mathrm{m}^{-1} \cdot \mathrm{K}^{-1}$ to $0.0481 \mathrm{~W} \cdot \mathrm{m}^{-1} \cdot \mathrm{K}^{-1}$, respectively [144].

Main goal of this review was to gather the information about existing studies about peat based composites. Majority of studies are based on peat based composites with oil based synthetic polymers as a binder such as PP, HDPE and PLA. The reason for that may be the fact, that biobinders cant provide composite with same parameters as synthetic ones. Among the bio-degradable films studied, starch and starch-PVA (8:2) films exhibited the highest strength. However, their strength is about half that of the synthetic polymer films [145].

Biobinders are used in applications, where the strength of the material is not crucial and other parameters such as porosity and thermal properties are crucial. For example, in agricultural sector.

Peat composites without binders are mostly studied in construction industry, where materials with low density and good thermal insulation properties are obtained.

\section{Deep processing peat products existing on the market}

As known peat is having very porous structure, containing large amount of water and other organic compounds. With a lot of functional groups in peat, especially humic and fulvic acids [31], it shows potential use of peat resources in much more meaningful way than used now, not only as fertilizer in nearly raw condition or in briquettes as fuel for heating, but as well for extracting organic compounds from it - commonly humic and fulvic acid extracts; activated carbon can be produced from various biomasses, including peat, and there are also several underdevelopment applications - wastewater treatment, oil spill collection, biological filters, biosorbers [146]. Peat resources are not local, they are global, which means products from peat can be both - economically and environmentally profitable in several locations, not only in one region [31], [146]. Further in text most common peat products, prices (if available) and applications are described, starting with simplest applications.

One of the most commonly used peat product is raw, slightly processed peat - peat substrate as fertilizer (peat moss) in horticulture. Because of high water and organic compound amount, such substrate has great application as fertilizer - water and other 
nutrients helps for development of roots, also peat has air-holding capacity necessary for roots, and as well for plant respiration and for supporting the essential functions of water and nutrient uptake. Because of high cation exchange capacity, several nutrients (potassium, calcium ions etc.) are kept in peat, rather than flushed away with water, and then released for plant, making the growing process more efficient [147]. Because of high content of functional groups, such as hydroxyl, keto, aldehyde, carboxylic and ether [31], peat substrate in general is acidic, necessary for specific plants to obtain acidic soil. In general peat substrate is made by removing the higher plant material, sphagnum peat moss (peat substrate) is harrowed and turned upside and dried on the field for 2-3 days, then collected (for an example with vacuum harvester) and filled in bags [147]. In Table 8 several peat mosses (peat substrates) available in market are compared.

Table 8. Peat substrate products for horticulture.

\begin{tabular}{|c|c|c|c|}
\hline Product and short description & $\begin{array}{l}\text { Made } \\
\text { in }\end{array}$ & $\begin{array}{c}\text { Price } \\
(€ / 100 L)\end{array}$ & Reference \\
\hline Peat substrate "KKS-1" (with additives, $\mathrm{H}_{2}-\mathrm{H}_{5}, \mathrm{pH}$ : 5.2-6.0) & Latvia & $2.92-3.65$ & [147] \\
\hline $\begin{array}{l}\text { Finely sifted natural moss peat "EKO kūdra" (no additives, } \\
\left.\qquad \mathrm{H}_{2}-\mathrm{H}_{5}, \mathrm{pH}: 2.9-3.5\right)\end{array}$ & Latvia & $1.99-2.54$ & [147] \\
\hline Peat substrate “KKS-2" (with additives, $\mathrm{H}_{2}-\mathrm{H}_{5}, \mathrm{pH}$ : 5.2-6.0) & Latvia & $3.24-3.86$ & {$[147]$} \\
\hline $\begin{array}{l}\text { Peat substrate "PEATFIELD STANDARD PL-1" (with } \\
\text { additives, } \mathrm{pH}: 5.5-6.5 \text { ) }\end{array}$ & Ukraine & $3.90-4.55$ & [147] \\
\hline Acidic peat “Eco plus" (with additives, pH: 2.8-3.8) & Ukraine & $5.94-6.20$ & [147] \\
\hline $\begin{array}{l}\text { Peat substrate "Gold Label Special Mix Light" (with } \\
\text { additives, } \mathrm{pH}=6,2 \text { ) }\end{array}$ & Sweden & $19.56-24.44$ & {$[147]$} \\
\hline
\end{tabular}

Price of peat or peat substrate for horticulture may vary due to additives in substrate, but it can be concluded that peat produced in Latvia with reliable quality is not expensive, comparing to other substrates from different countries. For an example last substrate in table is highly modified with additives, but second (basically peat) does not have any additives and prices are 10 times different.

Next peat product is peat briquettes. When peat burns, little ash is left from 2 to $10 \%$ of mass, and heat output is approximately $8000 \pm 500 \mathrm{~kJ}$ per $\mathrm{kg}$ of peat. To produce such briquettes, sod peat is crushed, screened and stored, to inhibit break-up of the peat. Then peat is dried, screened and sent to a briquetting unit. All the fines from previous screenings can be used in peat briquettes [146]. To reduce health effects from burning peat briquettes, peat or briquettes is carbonized at $450{ }^{\circ} \mathrm{C}$. Comparing peat and charcoal for heating purposes, peat is cheaper to use in certain areas, however valuable organic compounds are not extracted, but destroyed in carbonization process, showing that peat used as fuel is not meaningful way to use peat resources. Of course, in several locations where are massive peat resources and lack of other resources for heating fuel, peat could be used in such way, but the other potential uses for peat are much more efficient. Of course, peat ashes contains some valuable compound and can be used as fertilizer, but not as efficient as raw peat [146], [148]. In Table 6 some available peat and other firing briquettes are compared.

Table 6. Comparison between peat and other briquettes [147].

\begin{tabular}{|c|c|c|c|}
\hline Material & Short description & $\begin{array}{c}\text { Heat value } \\
\text { (kcal/kg) }\end{array}$ & $\begin{array}{c}\text { Price } \\
(€ / 100 \mathrm{~kg})\end{array}$ \\
\hline
\end{tabular}




\begin{tabular}{cccc}
\hline Peat & $\begin{array}{c}\text { Peat briquettes from Belarus, burns for 6- } \\
\text { 12h, little smoke and soot. }\end{array}$ & $3700-3900$ & $12-14.58$ \\
Peat & $\begin{array}{c}\text { Peat briquettes from Ireland, burns longer } \\
\text { than wood and produces less heat. } \\
\text { Briquettes from wood chips - birch wood } \\
\text { (Latvia), low density and water content, } \\
\text { hood chips }\end{array}$ & $4302-5258$ & $42.48-62$ \\
& $\begin{array}{c}\text { higher heat value than from wood. } \\
\text { Wooden } \\
\text { Briquettes from wooden biomass (India), } \\
\text { preferred use for boilers. }\end{array}$ & 3500 & $11.90-16.20$ \\
\hline
\end{tabular}

From this comparison it is visible that price and heat values for both - peat briquettes and wood briquettes may vary from manufacturer, but it can be concluded that in some locations peat is better alternative for heating, if any other fuel is not available or has to be transported long way, but briquettes from wood chips or biomass (by-product) is better option - cheaper and with higher heat value.

One of the more meaningful way to use peat is extracting valuable compound from peat - humic and fulvic acids. Alkaline extraction is used for such application - after applying sodium carbonate/hydroxide or potassium hydroxide to peat, extracting humic and fulvic acids, and leaving a solid residue formed by humin and inorganic matter. To separate humic and fulvic acids, obtained extract is further acidified, leaving fulvic acids in solution and precipitating humic acids. Using these humic substances, organic fertilizer is produced, improving physical and chemical structure of the soil and also providing a source of organic carbon; potassium is a primary nutrient for plants, showing no need for purification of obtained potassium humates, but it can be used straight away [91]. On the market lots of various organic fertilizers, containing humic acids are available, but often humates used in fertilizers are not obtained from peat, but for an example - from leonardite [147]. The most binding product found is "Potassium Humate Liquid" ("Liquid Peat - Potassium Humate (Humic Acid)), made in Russia, which contains 65 \% humic acids (not mentioned precisely, but probably in form of potassium salts) and other additives, making this product as very efficient fertilizer. In Table 7 quick product comparison between "Liquid peat potassium humate" and potassium humate from leonardite is shown.

Table 7. Comparison between potassium humate fertilizer from peat and leonardite [147].

\begin{tabular}{|c|c|c|}
\hline Raw material & Short description, use & $\begin{array}{c}\text { Price }(€ / 1000 \mathrm{~L} \\
\text { of ready } \\
\text { fertilizer })\end{array}$ \\
\hline Leonardite & $\begin{array}{l}\text { Organic fertilizer, containing humic acid potassium salts } \\
\text { and other additives ( } 65-70 \% \text { humic acid), made in China, } \\
\text { must use } 1-5 \mathrm{~kg} \cdot \mathrm{ha}^{-1} \text { (differs from the type of use), must } \\
\text { dissolve in water to use }(0.8-2.0 \mathrm{~kg} \text { per } 1000 \text { litres of } \\
\text { water), } \mathrm{pH} 8-10,\end{array}$ & $\begin{array}{c}0.68-1.70 \\
\text { (price not } \\
\text { specified } \\
\text { clearly in shop) }\end{array}$ \\
\hline Peat & 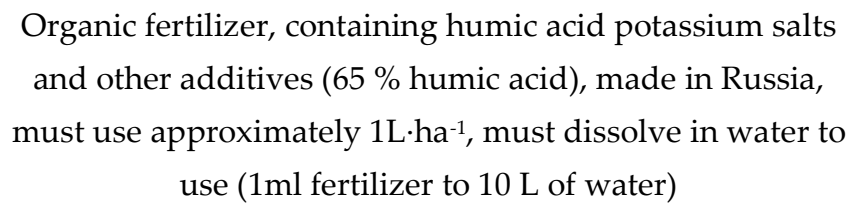 & 13.52 \\
\hline
\end{tabular}


It is clearly visible from table that such fertilizer made from peat extract could be way more expensive than made from leonardite, but it is possible that there are cheaper humate fertilizers on market made from peat, but not advertised like that. Also compared leonardite fertilizer is sold in large quantities (meant for agricultural use), but the one extracted from peat - in $100 \mathrm{ml}$ bottles (for use in small garden or greenhouse), and this difference may be changing price significantly.

Another product with wide application can be made from peat- activated carbon. When peat is pyrolysed, it is converted from a substance containing much hydrogen and oxygen into substance with a very high carbon content - peat coke. Activated carbon produced from peat is done by preparing peat coke at $500{ }^{\circ} \mathrm{C}$, then activation process is carried out at $600-800^{\circ} \mathrm{C}$ for $20-30 \mathrm{~min}$ [146]. There are two main methods for carbon activation - physical (thermal) and chemical (using activators, for an example $\mathrm{ZnCl} 2$ ) activation. Even though peat resources are widely available, activated carbon from peat is described as expensive and made out from non-renewable resource (peat renews slowly) and activated carbon can be made from lots of various materials - palm shell, palm steam, bamboo, coconut shell, olive mill, nut shells, corn cob, pomegranate seed, birch, wheat straw, rice husk, woody birch and etc. These materials are described as agricultural waste - they don't have any efficient further use like peat does, meaning these materials have better application for activated carbon [149]. In Table 8 various activated carbons from different raw materials available on market are compared.

From table it can be concluded that activated carbon from peat is not really more expensive than from coal or wood activated carbon, of course, not all the products on the market are shown in the table, but prices are from one distributor (Sigma-Aldrich). The last one in the table - activated charcoal as dietary supplement - is for comparison between use in chemistry and in diet. Unfortunately, reliable source for raw material of such activated charcoal was not found.

Table 8. Activated carbons available on market.

\begin{tabular}{|c|c|c|c|}
\hline Raw material & Short description & $\begin{array}{l}\text { Price } \\
(€ / 1 \mathrm{~kg})\end{array}$ & Reference \\
\hline Coal & $\begin{array}{l}\text { Norit GAC } 1240 W, \text { steam activated, } \\
\text { granular, for use in chemistry }\end{array}$ & 190 & [147] \\
\hline Wood & $\begin{array}{l}\text { Norit CA1, chemically activated, powder, } \\
\text { for use in chemistry }\end{array}$ & 172 & [147] \\
\hline Peat & $\begin{array}{c}\text { Norit }{ }^{\circledR} \text { SX2, powder, multi-purpose, steam } \\
\text { activated and acid washed }\end{array}$ & 210.80 & [147] \\
\hline Peat & $\begin{array}{c}\text { Norit PK 1-3, steam activated, granular, for } \\
\text { use in chemistry }\end{array}$ & 154.40 & [147] \\
\hline Not specified & Activated charcoal as dietary supplement & 112 & [147] \\
\hline
\end{tabular}

The next group of peat products are underdevelopment products - some research is still being made or it is done, but these products cannot replace the ones in the market. Further such applications as wastewater treatment, oil spill collection and biological filters are described. Peat can be used to remove phosphates, also nitrogen compounds and pathogenic bacteria from wastewater, also lowering the biological oxygen demand from it. Some experiments are carried out by releasing wastewater over peat bog, but in order to use such technology in conventional way special filters must be constructed, for an example peat-sand filter (Goy-Green Type Filter Bed) for filtering wastewater. Also wastewaters from slaughterhouses, which contains a lot of proteins, iron, fats and even phosphorus can be filtered using peat, as well different textile and dye effluents [146]. Oil 
spills can be collected from the water surface, using peat-based sorbents. Due to high absorbing capabilities, such sorbents can take oil up to 16 times its weight, together with relatively low cost of peat it shows opportunity for such use. Oil is being absorbed by peat because of capillary and adsorption ability of it, different sorts of peat puts out different results, peat collected from the top surface is described as the most efficient [150]. Wheat straw is used for such application, but it only can take oil up to 5 times of its weight yy. Peat can be used as biological filter material in similar way used for wastewater treatment, but for odour removal from gaseous effluent and for removal of different organic compounds from vapours. These gaseous effluents are sent through peat, where they are absorbed and oxidized to simpler compounds - carbon dioxide and water [146]. There are a lot of potential uses described in literature, indicating that peat has gained interest in science.

In conclusion it can be said that peat is a valuable resource with big potential use in various spheres, replacing other resources - fossil ones or with greater potential use for other application. Commonly peat is used as fertilizer in nearly raw state or as heating fuel in dried - briquette state, but also humate extracts and activated carbon can be produced from peat. After humate extraction some peat mass remains, that potentially could be used as heating fuel instead of raw peat with valuable components in it. A lot of research and commercialization is up for peat resource.

\section{Evaluation criteria for fen peat in high added-value products and applications}

The evaluation of fen peat for utilisation in high added-value products and applications is principally based on HS and humic acid content and their proven beneficial properties and effects on the biological life. Peat HS have physical, chemical, biological and environmental features, all of which can be used to produce products with high added value.

Peat HS are formed through the chemical and biological degradation of plant organic matter. Fen peat HS, in general, are the lignin decomposition products in vascular tissues of higher plants. This makes them different from raised bog peat HS, which are the final product of bryophyte decomposition. However, the physicochemical properties of HS are rather similar in both types of peat. The main fractions of HS are humic and fulvic acids. Taking into consideration the amount, the humic acids are the major extractable component of fen peat HS. Differences between humic and fulvic acids can be explained by variations in their molecular weight, the number of functional groups, such as carboxyl and phenolic hydroxyl groups, and the extent of HS polymerization. The carbon and oxygen content, the acidity and the degree of polymerization all change systematically with increasing molecular weight of HS.

Fen peat humic acids can be considered as the component with the highest beneficial value. Peat humic acids can be described as complex aromatic macromolecules that contain amino acids, amino sugars, peptides, and aliphatic compounds, which are all involved in linkages between the aromatic functional groups. Well defined and globally approved structure of humic acids is yet to be defined. Yet, the hypothetical structure for humic acids contains free and bound phenolic hydroxyl groups, quinone structures, nitrogen and oxygen as bridge units and carboxyl groups, which are variously placed on aromatic rings. The major beneficial feature of humic acids is their ability to form complexes, which depends on the oxygen-containing functional group content, such as carboxyl, phenolic hydroxyl and carbonyl groups. Peat humic acids have high cation exchange capacity and oxygen content and above average water holding capacity, all of which are key criteria for improved soil fertility and favourable plant growth. Furthermore, the humic acids can bind insoluble metal ions, oxides and hydroxides, and afterwards can release them slowly and continually to plants, when they are required. Peat humic acid products and applications can provide plants with a set of essential nutrients, vitamins and trace elements. 


\subsection{Physical effects of humic acids}

The application of peat humic acids on soil can physically modify and improve soil structure. One of the most beneficial features of humic acid applications is their ability to prevent high water and nutrient loss in light and sandy soils, while also improving soil fertility. At the same time, in heavy and compact soils, humic acid applications can improve soil aeration and water retention, hence preventing soil from cracking and erosion. Moreover, humic acid applications can increase soil water holding capacity and thus limiting the risk of potential drought. In addition, the black colour of humic acids allows soil to attract more solar energy and, in that way, also stimulate photosynthesis in plants and increase plant development and production.

\subsection{Chemical effects of humic acids}

The applications that are based on peat humic acids can change soil fixation properties, because humic acids can regulate $\mathrm{pH}$ and neutralize both acidic and alkaline environment, and optimize the nutrient and water uptake, increase soil buffering properties, chelate metal ions, retain water soluble inorganic fertilizers and reduce their leaching from crop root zone. Peat humic acids also possess high cation exchange capacity and can convert nutrient elements into available forms for plants. Peat humic acids also can enhance nitrogen uptake. Moreover, humic acid applications can improve the productivity of mineral fertilizers and release carbon dioxide from soil calcium carbonate, enabling its use in photosynthesis and limiting the appearance of toxic substances in soils.

\subsection{Biological effects of humic acids}

The humic acids can biologically stimulate plants and improve the microbial activity within the soil. Peat humic acids can accelerate plant enzymes and increase their production. In general, peat humic acids work as organic catalysts in most plant-based biological processes; they stimulate plant growth and allow the proliferation of required microorganisms in soil. The humic acids also enhance the natural resistance of plants against various diseases and pests; they stimulate plant root growth and enable better uptake of nutrients. The application of humic acids onto soil can increase root respiration and formation; it promotes the development of chlorophyll, sugars and amino acids in plants, and support photosynthesis. The humic acids induce the increase in vitamin and mineral content in plants; they thicken the cell walls in fruits and can prolong fruit storing and shelf time after picking. Peat humic acids also can increase germination rate and viability of seeds; they can stimulate plant growth by accelerating cell division and enhancing the rate of formation in root systems; they can improve the quality of yields, their physical appearance and nutritional value.

\subsection{Environmental effects of humic acids}

The humic acids have diverse ecological effects on the environment and present an effective solution for a variety of environmental issues. The applications of peat humic acids can limit nitrate leaching from soil and any adverse mixing of pesticides with groundwaters. Furthermore, humic acid applications can optimize nutrient efficiency and significantly improve plant development. The humic acid applications can reduce negative effects, such as salination, which is typically caused by water-soluble mineral fertilizers. Peat humic acids can increase the ability of soil colloids to combine, hence they can limit soil erosion and improve overall plant root systems. Moreover, the humic acids chelate nutrients to obtain a suitable form for plants to utilize. Furthermore, water holding capacity of soils is increased considerably when humic acids are applied, which means that the use of water can be reduced substantially.

\subsection{Medical effects of humic acids}


The veterinary applications that are based on humic acids can be dermal, peroral or subcutaneous and can be used for a variety of therapeutic, prophylactic and nutritional purposes. The humic acids are natural, hence their applications in veterinary can be used as an alternative for antibiotics. For instance, humic acid applications can inhibit inflammation, this ability is believed to be related to high flavonoid content in humic acids. Phenolic groups, in general, have a variety of immunological effects in cattle animals. The macro-colloidal structure of humic acids allows them to form a protective film on the mucosa of the gastrointestinal tract and thus they can protect cattle against infection and toxins and improve the absorbing and transforming function for nutrients. The humic acids are high molecular compounds, hence their preparations can remain in the gastrointestinal tract without self-resorption. The humic acid applications can also reduce the resorption of toxic metabolites and improve the protection of the peripheral vascular system and damaged mucous cells. The humic acids are ergotropic and their applications allow to stabilize the intestinal flora and ensure an improved nutrient utilization in animal feed by enhancing the feed efficiency, meaning that the liveweight of cattle animals can be increased without increasing the amount of the feed.

\section{Final recommendation and conclusions}

The requirement of fen (black) peat extraction and the production of new products and applications from this material, or any new peat deposit recultivation techniques are high on agenda, because fen peat layer is uncovered and subjected to oxidation and mineralization when raised bog peat excavation is completed. Correspondingly, in fens that are converted into agricultural lands large scale peat oxidation and mineralization also takes place, hence significantly increasing content of greenhouse gases in the atmosphere. Furthermore, use of peat resources can be completer and more efficient than currently implemented measures if the industrial value of fen peat is added.

Notwithstanding that fen peat and the components of it technically can be used in a wide variety of products and applications, it is advised to put the main emphasis on use of fen peat HS and humic acids, which are isolated from black peat in raised bog peat deposits. Whilst it is possible to use fen peat and mire vegetation from natural fen ecosystems, it is strongly advised to use only black peat and leave fens intact, in that way it is possible to preserve natural values and mitigate human induced climate change. Moreover, it is recommended to reconsider agricultural activities on previously into agricultural lands transformed fens.

Peat humic acids, no matter the peat type, have rather similar physicochemical properties and thus regardless of whether they are obtained from raised bog or fen peat they can be used in similar products and applications. At the same time, the proportion of humic and fulvic acids often differs between raised bog and fen peat and even between different fen peat subtypes and this situation has to be taken into consideration when looking for new prospects of products or applications.

The physicochemical properties of peat HS and humic acids are proven to be beneficial for plant and animal life development and quality. Furthermore, they can be used to mitigate and reverse negative impact of anthropogenic activities on the environment. Three main areas, where use of fen peat HS and humic acids can be taken into major consideration is horticulture, environmental remediation and medicine. In horticulture fen peat products can be used to improve soil substrate properties, hence increasing plant growth and yields while also reducing overall costs. In environmental remediation fen peat preparations can be used for soil recultivation or to reduce environmental pollution, such as wastewater contamination. In medicine, such properties as peat thermal capacity and the ability of humic acids to form complexes can be used to produce anti-inflammatory and antiviral drugs. These medical benefits can also be used in veterinary medicine as nutritional supplements for livestock feed. 
Supplementary Materials: The following are available online at www.mdpi.com/xxx/s1, Figure S1: title, Table S1: title, Video S1: title.

Author Contributions: Conceptualization, J.K., M.K. and A.S.; methodology, J.O. and V.M.; formal analysis, A.T., K.I., V.M., and V.L.; resources, J.K., V.L. and A.S.; data curation, A.T. K.I and A.S.; writing-original draft preparation, J.K., M.K., A.T., K.I., V.L., and A.S. writing - review and editing, J.O. and V.M.; supervision, A.S and M.K.; project administration, V.L.; funding acquisition, V.L. and V.M. All authors have read and agreed to the published version of the manuscript.

Funding: Please add: This research was funded by by the Latvian Council of Science within the scope of the project "Innovative bio-based composite granules for collecting oil spills from the water surface (InnoGran)" (No. lzp-2020/2-0394). The work resulting within the network collaboration in the frame of COST Action CA18224 GREENERING ("Green Chemical Engineering Network towards upscaling sustainable processes"). COST Actions are funded within the EU Horizon 2020 Programme. The authors are grateful for the support.

Institutional Review Board Statement: Not applicable.

Informed Consent Statement: Not applicable.

Conflicts of Interest: The authors declare no conflict of interest.

\section{References}

[1] D. A. Weixelman and D. J. Cooper, Assessing proper functioning condition for Fen areas in the Sierra Nevada and Southern Cascade Ranges in California : a user guide, no. April 2009. 2009.

[2] J. Peters, M. von Unger, and J. Peters Moritz von Unger, Peatlands in the EU Regulatory Environment Peatlands in the EU Regulatory Environment Survey with case studies on Poland and Estonia. 2017.

Citizens

Information

Board.

European." https://www.citizensinformation.ie/en/environment/environment_and_the_law/eu_environmental_law.html.

“Environmental Liability. An official website of the European Union. European Commission," Online. 2021, [Online]. Available: https://ec.europa.eu/research/foresight/index.cfm.

“European Climate Law. An official website of the European Union. European Commission.” https://ec.europa.eu/clima/euaction/european-green-deal/european-climate-law_en.

[6] "Nature and Biodiversity Law. An official website of the European Union. European Commission," 2012. http://ec.europa.eu/environment/nature/invasivealien/index_en.htm.

[7] F. Ekardt, B. Jacobs, J. Stubenrauch, and B. Garske, "Peatland Governance: The Problem of Depicting in Sustainability Governance, Regulatory Law, and Economic Instruments," Land, vol. 9, no. 3, pp. 1-25, 2020, doi: 10.3390/land9030083.

[8] “Global Peatlands Initiative. UN Environment." https://www.globalpeatlands.org/new-ipcc-special-report-highlightsimportance-of-peatlands-for-climate-change-mitigation/.

[9] F. Schierhorn et al., "Large greenhouse gas savings due to changes in the post-Soviet food systems," Environ. Res. Lett., vol. 14, no. 6, 2019, doi: 10.1088/1748-9326/ab1cf1.

[10] K. S. Godwin, J. P. Shallenberger, D. J. Leopold, and B. L. Bedford, “Linking landscape properties to local hydrogeologic gradients and plant species occurrence in minerotrophic fens of New York State, USA: A hydrogeologic setting (HGS) framework," Wetlands, vol. 22, no. 4, pp. 722-737, 2002, doi: 10.1672/0277-5212(2002)022[0722:LLPTLH]2.0.CO;2.

[11] H. Rydin and J. Jeglum, The biology of peatlands, second edition, no. January 2013. 2013.

[12] W. Shotyk, "Natural and anthropogenic enrichments of $\mathrm{As}, \mathrm{Cu}, \mathrm{Pb}, \mathrm{Sb}$, and $\mathrm{Zn}$ in ombrotrophic versus minerotrophic peat bog profiles, Jura Mountains, Switzerland," Water. Air. Soil Pollut., vol. 90, no. 3-4, pp. 375-405, 1996, doi: 10.1007/BF00282657.

[13] B. A. Keddy, Wetland Ecology: Principles and Conservation (2nd ed.). 2010.

[14] P. Nomals, Latvijas purvi. Latvijas zeme, Daba un Tauta, II Latvijas Daba. 1936.

[15] D. Yeloff and D. Mauquoy, “The influence of vegetation composition on peat humification: Implications for palaeoclimatic 
studies," Boreas, vol. 35, no. 4, pp. 662-673, 2006, doi: 10.1080/03009480600690860.

[16] J. A. C. Fortescue, Environmental Geochemistry. A Holistic Approach. Springer-Verlag New York, 1980.

[17] H. Joosten and D. Clarke, Wise use of mires and peatlands - Background and principles including a framework for decision-making. 2002.

[18] F. Tanneberger et al., "The peatland map of Europe," Mires Peat, vol. 19, no. 2015, pp. 1-17, 2017, doi: 10.19189/MaP.2016.OMB.264.

[19] H. Joosten, F. Tanneberger, and A. Moen, "Mires and peatlands of Europe: Status, distribution and conservation. Schweizerbart Science Publisher. Stuttgart," p. 780, 2017.

[20] Jan Seffer; M. Janak; Viera Sefferova, “Management of Natura 2000 habitata Alluvial meadows of river valleys of the Cnidion dubii 6440," 2008. doi: 10.13140/RG.2.2.19172.60802.

[21] W. Dembek, H. Piórkowski, and M. Rycharski, Mokradła na tle regionalizacji fizycznogeograficznej Polski. Wiadomości IMUZ 97. 2000.

[22] U. Valk, “Utilization of peatlands in Estonia: a historical review," in Proc. 8th Int. Peat Congress, Sect. 1, Leningrad, USSR, 1988, pp. 78-82.

[23] A. Barthhelmes, J. Couwenberg, M. Risager, C. Tegetmeyer, and H. Joosten, Peatlands and Climate in a Ramsar context - : A Nord-Baltic Perspective. 2015.

[24] A. Borgmark, "Holocene climate variability and periodicities in south-central Sweden, as interpreted from peat humification analysis," Holocene, vol. 15, no. 3, pp. 387-395, 2005, doi: 10.1191/0959683605hl816rp.

[25] H. Rydin and J. K. Jeglum, “The Biology of Peatlands, 2nd edition," Austral Ecol., vol. 40, no. 8, pp. e18-e19, 2013, doi: 10.1111/aec.12290.

[26] A. McBride et al., The Fen Management Handbook. 2011.

[27] S. Abel, J. Couwenberg, T. Dahms, and H. Joosten, “The Database of Potential Paludiculture Plants (DPPP) and results for Western Pomerania," Plant Divers. Evol., vol. 130, no. 3-4, pp. 219-228, 2013, doi: 10.1127/1869-6155/2013/0130-0070.

[28] L.-E. Parent and P. Ilnicki, Organic soils and peat materials for sustainable agriculture. 2002.

[29] L. Mayhew, “Humic Substances in Biological Agriculture,” Agres, vol. 34, pp. 1-2, 2004.

[30] D. Dave, R. Alharathi, and A. Ghaly, "Sequential Remediation Processes for Effective Removal of Oil from Contaminated Soils," Am. J. Environ. Sci., vol. 7, no. 5, pp. 477-491, 2011.

[31] M. Ranđelović, M. Momčilović, M. Purenović, A. Zarubica, and A. Bojić, "The acid-base, morphological and structural properties of new biosorbent obtained by oxidative hydrothermal treatment of peat," Environ. Earth Sci., vol. 75, no. 9, p. 764, May 2016, doi: 10.1007/s12665-016-5242-0.

[32] B. C. O'Kelly and V. Sivakumar, "Water Content Determinations for Peat and Other Organic Soils Using the Oven-Drying Method," Dry. Technol., vol. 32, no. 6, pp. 631-643, Apr. 2014, doi: 10.1080/07373937.2013.849728.

[33] L. Fagernäs, V. Arpiainen, and E. Kuoppala, “Organic compounds released in fluidized-bed drying of peat, bark and lignite," Fuel Process. Technol., vol. 29, no. 1-2, pp. 107-118, Nov. 1991, doi: 10.1016/0378-3820(91)90021-4.

[34] W. Shotyk and T. Noernberg, "Sampling, handling, and preparation of peat cores from bogs: review of recent progress and perspectives for trace element research," Can. J. Soil Sci., vol. 100, no. 4, pp. 363-380, Dec. 2020, doi: 10.1139/cjss-2019-0160.

[35] F. Rezanezhad, J. S. Price, W. L. Quinton, B. Lennartz, T. Milojevic, and P. Van Cappellen, "Structure of peat soils and implications for water storage, flow and solute transport: A review update for geochemists," Chem. Geol., vol. 429, 2016, doi: 10.1016/j.chemgeo.2016.03.010.

[36] A. Mikhailov, A. Zhigulskaya, and O. Garmaev, "An integrated approach to strip mining of peat," IOP Conf. Ser. Earth Environ. Sci., vol. 378, p. 012087, Nov. 2019, doi: 10.1088/1755-1315/378/1/012087.

[37] O. Misnikov, “Basic Technologies and Equipment Used for Peat Deposits Development in Foreign Countries," E3S Web Conf., 
vol. 41, p. 01046, Jun. 2018, doi: 10.1051/e3sconf/20184101046.

[38] K. Irtiseva, J. Baronins, J. Krūmiņš, J. Ozolins, M. Kḷaviņš, and O. Medne, “Development of Peat Processing Methods for Production of Innovative Products," Key Eng. Mater., vol. 850, pp. 9-15, Jun. 2020, doi: 10.4028/www.scientific.net/KEM.850.9.

[39] E. Ortega-Rivas, "Separation Techniques for Solids and Suspensions," in Food Engineering Series, 2012, pp. 131-197.

[40] Xiao Zhiyong, "Peat separation and purification method," CN103785544A.

[41] E. Lintingre, F. Lequeux, L. Talini, and N. Tsapis, "Control of particle morphology in the spray drying of colloidal suspensions," Soft Matter, vol. 12, no. 36, pp. 7435-7444, 2016, doi: 10.1039/C6SM01314G.

[42] T. Shajahan and W.-P. Breugem, "Influence of Concentration on Sedimentation of a Dense Suspension in a Viscous Fluid," Flow, Turbul. Combust., vol. 105, no. 2, pp. 537-554, Aug. 2020, doi: 10.1007/s10494-020-00172-8.

[43] J. P. Dijkshoorn, M. A. I. Schutyser, R. M. Wagterveld, C. G. P. H. Schroën, and R. M. Boom, “A comparison of microfiltration and inertia-based microfluidics for large scale suspension separation," Sep. Purif. Technol., vol. 173, pp. 86-92, Feb. 2017, doi: 10.1016/j.seppur.2016.09.018.

[44] W. Peukert and J. Walter, "Centrifugation: Analytical Ultracentrifugation," in Reference Module in Chemistry, Molecular Sciences and Chemical Engineering, 3rd ed., no. September, Elsevier, 2018, pp. 1-12.

[45] E. Dumay, D. Chevalier-Lucia, L. Picart-Palmade, A. Benzaria, A. Gràcia-Julià, and C. Blayo, "Technological aspects and potential applications of (ultra) high-pressure homogenisation," Trends Food Sci. Technol., vol. 31, no. 1, pp. 13-26, May 2013, doi: 10.1016/j.tifs.2012.03.005.

[46] A. Shishkin, A. Korjakins, and V. Mironovs, “Using of Cavitation Disperser, for Porous Ceramic and Concrete Material Preparation," Int. J. Environ. Chem. Ecol. Geol. Geophys. Eng., vol. 9, no. 5, pp. 511-515, Jun. 2015.

[47] A. Bogdashov et al., "Experimental study of the dynamics of microwave pyrolysis of peat," in Proceedings of Universities Applied Chemistry and Biotechnology, 2019, vol. 9, no. 4, pp. 750-758, doi: 10.21285/2227-2925-2019-9-4-750-758.

[48] T. O. Krapivnitckaia et al., "Microwave pyrolysis of peat: Simulations and experimental results," in International Conference on Infrared, Millimeter, and Terahertz Waves, IRMMW-THz, 2018, pp. 1-2, doi: 10.1109/IRMMW-THz.2018.8509993.

[49] M. Cunico, "Pyrolysis of peat : an experimental investigation," 2015.

[50] Y. Duan, B. Wu, J. He, and T. Sun, “Characterization of gases and solid residues from closed system pyrolysis of peat and coals at two heating rates," Fuel, vol. 90, no. 3, pp. 974-979, 2011, doi: 10.1016/j.fuel.2010.10.039.

[51] E. A. Salgansky, V. M. Kislov, S. V. Glazov, and M. V. Salganskaya, “Formation of liquid products at the filtration combustion of solid fuels," J. Combust., vol. 2016, 2016, doi: 10.1155/2016/9637082.

[52] R. Tabakaev, A. Astafev, Y. Dubinin, N. Yazykov, and V. Yakovlev, “Evaluation of autothermal peat pyrolysis realization for fuel processing technologies," Waste and Biomass Valorization, vol. 10, no. 4, pp. 1021-1027, 2019, doi: 10.1007/s12649-017-01157.

[53] R. Tabakaev, A. Astafev, Y. Shanenkova, Y. Dubinin, N. Yazykov, and V. Yakovlev, "Thermal effects investigation during biomass slow pyrolysis in a fixed bed reactor," Biomass and Bioenergy, vol. 126, pp. 26-33, 2019, doi: 10.1016/j.biombioe.2019.05.010.

[54] M. Morgalla, Benzene-char conversion and particle-vapor characterization in biomass gasification, no. 321.2018.

[55] K. Klein, M. Gross-Schmölders, J. M. De la Rosa, C. Alewell, and J. Leifeld, “Investigating the influence of instrumental parameters and chemical composition on pyrolysis efficiency of peat," Commun. Soil Sci. Plant Anal., vol. 51, no. 12, pp. 15721581, 2020, doi: 10.1080/00103624.2020.1784916.

[56] P. A. Maryandyshev et al., "Thermal decomposition and combustion of peat fuel," Solid Fuel Chem., vol. 53, no. 5, pp. 283288, 2019, doi: 10.3103/S0361521919050094.

[57] V. N. Melenevskii, M. A. Klimin, and S. V. Tolstokorov, "Diagenesis of organic matter in peat: Rock-Eval pyrolysis data," Geochemistry Int., vol. 57, no. 2, pp. 227-231, 2019, doi: 10.1134/S0016702919020071. 
[58] T. O. Krapivnitskaia, A. A. Bogdashov, A. N. Denisenko, and M. Y. Glyavin, “High-temperature microwave pyrolysis of peat," in 10th International Workshop 2017 "Strong Microwaves and Terahertz Waves: Sources and Applications," 2017, vol. 149, no. 02023, pp. 9-10, doi: 10.1051/epjconf/201714902023.

[59] U. S. Y. V. Indrawati, A. Ma'as, S. N. H. Utami, and E. Hanuddin, "Characteristics of three biochar types with different pyrolysis time as ameliorant of peat soil," Indian J. Agric. Res., vol. 51, no. 5, pp. 458-462, 2017, doi: 10.18805/IJARe.A-274.

[60] M. Klavins and D. Porshnov, “Development of a new peat-based oil sorbent using peat pyrolysis," Environ. Technol. (United Kingdom), vol. 34, no. 12, pp. 1577-1582, 2013, doi: 10.1080/09593330.2012.758668.

[61] H. Tolvanen, L. Kokko, and R. Raiko, "Fast pyrolysis of coal, peat, and torrefied wood: Mass loss study with a drop-tube reactor, particle geometry analysis, and kinetics modeling," Fuel, vol. 111, pp. 148-156, 2013, doi: 10.1016/j.fuel.2013.04.030.

[62] J. Lee, X. Yang, H. Song, Y. S. Ok, and E. E. Kwon, “Effects of carbon dioxide on pyrolysis of peat,” Energy, vol. 120, pp. 929936, 2017, doi: 10.1016/j.energy.2016.11.143.

[63] A. V. Shumovskii, E. G. Gorlov, and M. A. Noshin, "Production of metallurgical coke by the pyrolysis of peat, biomass, and tar mixtures," Solid Fuel Chem., vol. 54, no. 1, pp. 25-31, 2020, doi: 10.3103/S0361521920010085.

[64] M. Wiśniewska and P. Nowicki, "Peat-based activated carbons as adsorbents for simultaneous separation of organic molecules from mixed solution of poly(acrylic acid) polymer and sodium dodecyl sulfate surfactant," Colloids Surfaces A Physicochem. Eng. Asp., vol. 585, no. August 2019, p. 124179, 2020, doi: 10.1016/j.colsurfa.2019.124179.

[65] D. V. Ermolaev, S. S. Timofeeva, S. I. Islamova, K. S. Bulygina, and M. F. Gilfanov, "A comprehensive study of thermotechnical and thermogravimetric properties of peat for power generation," Biomass Convers. Biorefinery, vol. 9, no. 4, pp. 767-774, 2019, doi: 10.1007/s13399-019-00472-8.

[66] J. Yang, H. Chen, W. Zhao, and J. Zhou, “TG-FTIR-MS study of pyrolysis products evolving from peat," J. Anal. Appl. Pyrolysis, vol. 117, pp. 296-309, 2016, doi: 10.1016/j.jaap.2015.11.002.

[67] F. Girardello et al., "Characterization of Brazilian peat samples by applying a multimethod approach," Spectrosc. Lett., vol. 46, no. 3, pp. 201-210, 2013, doi: 10.1080/00387010.2012.702184.

[68] S. I. Islamova, S. S. Timofeeva, A. R. Khamatgalimov, and D. V. Ermolaev, “Kinetic Analysis of the Thermal Decomposition of Lowland and High-Moor Peats," Solid Fuel Chem., vol. 54, no. 3, pp. 154-162, 2020, doi: 10.3103/S0361521920030040.

[69] A. Korjakins, N. Toropovs, P. Kara, L. Upeniece, and G. Shakhmenko, "Application of Peat, Wood Processing and Agricultural Industry By-products in Producing the Insulating Building Materials," J. Sustain. Archit. Civ. Eng., vol. 1, no. 2, pp. 63-68, 2013, doi: 10.5755/j01.sace.1.2.2884.

[70] Y. Uraki, Y. Tamai, M. Ogawa, S. Gaman, and S. Tokurad, “Preparation of activated carbon from peat," BioResources, vol. 4, no. 1, pp. 205-213, 2009, doi: 10.15376/biores.4.1.205-213.

[71] N. Tsubouchi, M. Nishio, Y. Shinohara, J. Bud, and Y. Mochizuki, "Production of activated carbon from peat by with natural soda ash and effect of nitrogen addition on the development of surface area," Fuel Process. Technol., vol. 176, no. March, pp. 76-84, 2018, doi: 10.1016/j.fuproc.2018.03.014.

[72] L. Voropai, A. Sinitsyn, G. Tikhanovskaya, and O. Yukhtarova, “Technology for Producing Peat Heat-Insulating Boards Using Organosilicon Polymers," in E3S Web of Conferences, 2020, vol. 161, pp. 1-5, doi: 10.1051/e3sconf/202016101037.

[73] T. Vasiljeva and A. Korjakins, “The Development of Peat and Wood-Based Thermal Insulation Material Production Technology," Constr. Sci., vol. 20, no. 1, pp. 60-67, Apr. 2018, doi: 10.2478/cons-2017-0009.

[74] E. Petrauskaite, R. Vaiskunaite, D. Blumberga, and K. Ivanovs, "Experimental study of droplet biofilter packed with green sphagnum to clean air from volatile organic compounds," Energy Procedia, vol. 128, pp. 373-378, 2017, doi: 10.1016/j.egypro.2017.09.055.

[75] T. Hartikainen, P. J. Martikainen, M. Olkkonen, and J. Ruuskanen, "Peat biofilters in long-term experiments for removing odorous sulphur compounds," Water. Air. Soil Pollut., vol. 133, pp. 335-348, 2000. 
[76] B. Kleb, L. Benkovics, Á. Török, and J. Dömsödi, “Peat exploration for medical use,” Period. Polytech. Civ. Eng., vol. 43, no. 2, pp. 233-242, 1999.

[77] M. Trckova et al., “Peat as a feed supplement for animals: A review,” Vet. Med. (Praha)., vol. 50, no. 8, pp. 361-377, 2005, doi: 10.17221/5635-VETMED.

[78] Y. Gao et al., "Effects of fulvic acid on growth performance and intestinal health of juvenile loach Paramisgurnus dabryanus (Sauvage)," Fish Shellfish Immunol., vol. 62, pp. 47-56, 2017, doi: 10.1016/j.fsi.2017.01.008.

[79] N. N. Bambalov, “Use of peat as an organic raw material for chemical processing," Solid Fuel Chem., vol. 46, no. 5, pp. 282288, 2012, doi: 10.3103/S0361521912050023.

[80] E. D. Lodygin, I. I. Alekseev, R. S. Vasilevich, and E. V. Abakumov, “Complexation of lead and cadmium ions with humic acids from arctic peat soils," Environ. Res., vol. 191, no. 110058, pp. 1-10, 2020, doi: 10.1016/j.envres.2020.110058.

[81] J. Krumins, M. Klavins, and R. Krukovskis, “Characterisation of humic acids in fen peat,” Int. J. Agric. Resour. Gov. Ecol., vol. 16, no. 1, pp. 74-89, 2020, doi: 10.1504/IJARGE.2020.107066.

[82] J. Krumins, M. Klavins, and L. Kalnina, “Fen peat in environmentally friendly technologies," Energy Procedia, vol. 147, pp. 114-120, 2018, doi: 10.1016/j.egypro.2018.07.040.

[83] J. Sire and M. Klavins, "Influence of the humification process on the properties of peat humic acids," in Proceedings of the Latvian Academy of Sciences, Section B: Natural, Exact, and Applied Sciences, 2010, vol. 64, no. 3, pp. 167-173, doi: 10.2478/v10046010-0029-2.

[84] L. W. Szajdak, A. Jezierski, K. Wegner, T. Meysner, and M. Szczepanski, “Influence of Drainage on Peat Organic Matter : and Transformation," Molecules, vol. 25, no. 2587, pp. 1-27, 2020, [Online]. Available: www.mdpi.com/journal/molecules.

[85] W. Machado, J. C. Franchini, M. de Fátima Guimarães, and J. T. Filho, "Spectroscopic characterization of humic and fulvic acids in soil aggregates, Brazil," Heliyon, vol. 6, no. 6, 2020, doi: 10.1016/j.heliyon.2020.e04078.

[86] M. Klavins and O. Purmalis, "Properties and structure of raised bog peat humic acids," J. Mol. Struct., vol. 1050, pp. 103-113, 2013, doi: 10.1016/j.molstruc.2013.07.021.

[87] M. Klavins and O. Purmalis, “Characterization of Humic Acids from Raised Bog Peat,” Latv. J. Chem., vol. 52, no. 1, pp. 8397, 2014, doi: 10.2478/ljc-2013-0010.

[88] M. Klavins, O. Purmalis, S. Grandovska, and L. Klavina, "Properties of soil and peat humic substances from Latvia," Agron. Res., vol. 17, no. 2, pp. 499-508, 2019, doi: 10.15159/AR.19.045.

[89] R. Klocking, Y. Felber, M. Guhr, G. Meyer, R. Schubert, and J. I. Schoenherr, "Development of an innovative peat lipstick based on the UV-B protective effect of humic substances," Mires Peat, vol. 11, pp. 1-9, 2013.

[90] L. J. Huey, O. H. Ahmed, and N. M. Nik, "Effects of extractants on the yields and selected chemical characteristics of humic acids isolated from tropical saprists peat," Am. J. Appl. Sci., vol. 7, no. 7, pp. 933-936, 2010, doi: 10.3844/ajassp.2010.933.936.

[91] B. Saito and M. M. Seckler, "Alkaline extraction of humic substances from peat applied to organic-mineral fertilizer production," Brazilian J. Chem. Eng., vol. 31, no. 3, pp. 675-682, 2014, doi: 10.1590/0104-6632.20140313s00002512.

[92] W. G. Botero, L. C. Oliveira, A. D. M. Cavagis, A. H. Rosa, J. C. Rocha, and A. Santos, "Influence of the extractant on the complexing capacity of humic substances from peat for macro and micronutrients using continuous flow: Agricultural application and environmental impacts," J. Braz. Chem. Soc., vol. 24, no. 12, pp. 2015-2020, 2013, doi: 10.5935/01035053.20130252.

[93] M. Fuentes, R. Baigorri, G. González-Gaitano, and J. M. García-Mina, “New methodology to assess the quantity and quality of humic substances in organic materials and commercial products for agriculture," J. Soils Sediments, vol. 18, no. 4, pp. 13891399, 2018, doi: 10.1007/s11368-016-1514-2.

[94] C. Zaccone, P. Soler-Rovira, C. Plaza, C. Cocozza, and T. M. Miano, “Variability in As, Ca, Cr, K, Mn, Sr, and Ti concentrations among humic acids isolated from peat using $\mathrm{NaOH}, \mathrm{Na} 4 \mathrm{P} 2 \mathrm{O} 7$ and $\mathrm{NaOH}+\mathrm{Na} 4 \mathrm{P} 2 \mathrm{O} 7$ solutions," J. Hazard. Mater., vol. 167, 
no. 1-3, pp. 987-994, 2009, doi: 10.1016/j.jhazmat.2009.01.078.

[95] A. Trusek-Holownia and J. Ciereszko, “Solids removal from balneo peat extracts," Desalin. Water Treat., vol. 114, pp. 69-72, 2018, doi: 10.5004/dwt.2018.22517.

[96] P. Lestari, "Isolation of humic acid from peat soil and its application as an adsorbent for AuCl4- in solution," in AIP Conference Proceedings, 2017, vol. 1823, pp. 1-10, doi: 10.1063/1.4978112.

[97] M. M. Maroneze, L. Q. Zepka, J. G. Vieira, M. I. Queiroz, and E. Jacob-Lopes, “Comparative characterization of humic substances extracted from freshwater and peat of different apparent molecular sizes," Rev. Ambient. e Agua, vol. 9, no. 3, pp. 445-458, 2014, doi: 10.4136/1980-993X.

[98] R. Vasilevich, E. Lodygin, V. Beznosikov, and E. Abakumov, “Molecular composition of raw peat and humic substances from permafrost peat soils of European Northeast Russia as climate change markers," Sci. Total Environ., vol. 615, pp. 1229-1238, 2018, doi: 10.1016/j.scitotenv.2017.10.053.

[99] C. D. Matheson, C. Gurney, N. Esau, and R. Lehto, “Assessing PCR inhibition from humic substances,” Open Enzym. Inhib. J., vol. 3, no. 1, pp. 38-45, 2010, doi: 10.2174/1874940201003010038.

[100] E. A. Vialykh, S. A. Ilarionov, H. M. Abdelrahman, and I. A. Vialykh, "Changes in amino acids content of humic acids sequentially extracted from peat and sod-Podzolic soil," Can. J. Soil Sci., vol. 94, no. 5, pp. 575-583, 2014, doi: 10.4141/cjss2013064 .

[101] K. Sathya Prabha and A. K. Thajudeen, "Experimental Study on Properties of Concrete USNG Humic Acid," Int. J. Sci. Res. Publ., vol. 5, no. 8, pp. 1-4, 2015, [Online]. Available: www.ijsrp.org.

[102] C. L. Page and M. M. Page, Durability of concrete and cement composites. 2007.

[103] C. Piribauer, R. Knodt, S. Link, M. Engels, B. Stern, and N. Braun, "Humic Substances as Additives in Ceramic Clays and Bodies," Ceram. Forum Int., vol. 97, no. 1, pp. 36-42, 2020.

[104] M. Klavins, L. Eglite, and A. Zicmanis, "Immobilized humic substances as sorbents," Chemosphere, vol. 62, no. 9, pp. 15001506, 2006, doi: 10.1016/j.chemosphere.2005.06.015.

[105] D. von Borstel, G. Hoogestraat, and W. Ziechmann, “Efficiency of lignosulfonates and humic-related substances as expanders in negative electrodes of the lead/acid system," J. Power Sources, vol. 50, no. 1-2, pp. 131-140, 1994, doi: 10.1016/03787753(93)01892-L.

[106] "Black earth humic." https://blackearth.com/humic-acid-and-drilling-fluid/.

[107] C. R. Landis, "Foundry Sandadditives and Method of Casting Metal, Comprisinga Humic Acd-Containing Ore and in Stuactwated Carbon or Graphite for Reduced Woc Emissions," US5695554A, 1999.

[108] Y. M. Shulga et al., "Preparation of graphene oxide-humic acid composite-based ink for printing thin film electrodes for micro-supercapacitors," J. Alloys Compd., vol. 730, pp. 88-95, 2018, doi: 10.1016/j.jallcom.2017.09.249.

[109] F. J. Tibenham and N. S. Grace, “Compounding Natural Rubber with Lignin and Humic Acid,” Ind. Eng. Chem., vol. 46, no. 4, pp. 824-828, 1954, doi: 10.1021/ie50532a055.

[110] D. C. Olk, D. L. Dinnes, J. Rene Scoresby, C. R. Callaway, and J. W. Darlington, "Humic products in agriculture: potential benefits and research challenges-a review," J. Soils Sediments, vol. 18, no. 8, pp. 2881-2891, 2018, doi: 10.1007/s11368-0181916-4.

[111] L. P. Canellas et al., "Humic and fulvic acids as biostimulants in horticulture," Sci. Hortic. (Amsterdam)., vol. 196, pp. 15-27, 2015, doi: 10.1016/j.scienta.2015.09.013.

[112] “Science in hydroponics." https://scienceinhydroponics.com/2017/09/humic-acids-in-hydroponics.html.

[113] H. T. Lua and M. Böhme, "Influence of humic acid on the growth of tomato in hydroponic systems," Acta Hortic., vol. 548, no. March, pp. 451-458, 2001, doi: 10.17660/actahortic.2001.548.53.

[114] C. Liu, R. J. Cooper, and D. C. Bowman, "Humic acid application affects photosynthesis, root development, and nutrient 
content of creeping bentgrass," HortScience, vol. 33, no. 6. pp. 1023-1025, 1998, doi: 10.21273/hortsci.33.6.1023.

[115] Z. H. Shah et al., "Humic substances: Determining potential molecular regulatory processes in plants," Front. Plant Sci., vol. 9, no. March, pp. 1-12, 2018, doi: 10.3389/fpls.2018.00263.

[116] G. Ferrara and G. Brunetti, "Influence of foliar applications of humic acids on yield and fruit quality of table grape cv. italia," J. Int. des Sci. la Vigne du Vin, vol. 42, no. 2, pp. 79-87, 2008, doi: 10.20870/oeno-one.2008.42.2.822.

[117] G. C. Popescu and M. Popescu, "Yield, berry quality and physiological response of grapevine to foliar humic acid application," Bragantia, vol. 77, no. 2, pp. 273-282, 2018, doi: 10.1590/1678-4499.2017030.

[118] R. S. Nandhini, R. Shelishiyah, and P. Prakash, “Effect of Humic Acid on Seed Germination of Raphanus sativus L.," Int. J. Chem Tech Res., vol. 6, no. 9, pp. 4180-4185, 2014.

[119] L. A. Rodrigues, C. Z. Alves, C. H. Q. Rego, T. R. B. da Silva, and J. B. da Silva, “Humic acid on germination and vigor of corn seeds," Rev. Caatinga, vol. 30, no. 1, pp. 149-154, 2017, doi: 10.1590/1983-21252017v30n116rc.

[120] P. Conte, A. Agretto, R. Spaccini, and A. Piccolo, “Soil remediation: Humic acids as natural surfactants in the washings of highly contaminated soils," Environ. Pollut., vol. 135, pp. 515-522, 2005, doi: 10.1016/j.envpol.2004.10.006.

[121] A. Piccolo, Humic substances in terrestrial ecosystems. 1996.

[122] M. Jarošová, B. Klejdus, J. Kováčik, P. Babula, and J. Hedbavny, "Humic acid protects barley against salinity," Acta Physiol. Plant., vol. 38, no. 161, pp. 1-9, 2016, doi: 10.1007/s11738-016-2181-z.

[123] A. Sosnov and S. Sadovnikov, "Humic Acid-Based Sorbents for Area Decontamination," in 2013 EPA International Decontamination Research and Development Conference, 2013, no. November 2013, pp. 1-18.

[124] M. L. Pacheco, E. M. Peña-Méndez, and J. Havel, "Supramolecular interactions of humic acids with organic and inorganic xenobiotics studied by capillary electrophoresis," Chemosphere, vol. 51, no. 2, pp. 95-108, 2003, doi: 10.1016/S00456535(02)00846-9.

[125] L. M. Yates and R. Von Wandruszka, “Decontamination of polluted water by treatment with a crude humic acid blend," Environ. Sci. Technol., vol. 33, no. 12, pp. 2076-2080, 1999, doi: 10.1021/es980408k.

[126] N. A. Wall and G. R. Choppin, “Humic acids coagulation: Influence of divalent cations," Appl. Geochemistry, vol. 18, no. 10, pp. 1573-1582, 2003, doi: 10.1016/S0883-2927(03)00046-5.

[127] C. Ma, L. Li, G. Wang, and X. B. Yuan, "Synthesis and characterization of substituted-ammonium humic acid fluid loss additive for oil-based drilling fluids," Adv. Mater. Res., vol. 1004-1005, pp. 623-626, 2014, doi: 10.4028/www.scientific.net/AMR.1004-1005.623.

[128] W. Flaig, "Aspects of the Biochemistry of the Healing Effects of Humic Substances from Peat," Humic Subst. peats sludges Heal. Environ. Asp., pp. 346-356, 1997, doi: 10.1016/b978-1-85573-805-8.50038-0.

[129] R. Klöcking and B. Helbig, "Humic Substances, Medical Aspects and Applications of," Biopolym. Med. Pharm. Appl., pp. 3-16, 2001, doi: 10.1002/3527600035.bpol1013.

[130] E. W. Steinberg, Ecology of Humic Substances in Freshwaters, vol. 19, no. 5. 2003.

[131] S. M. Islam, R. Hashim, and A. B. M. Saiful Islam, "Behaviour of peat-added composite bricks in low-cost building construction," Materials Research Innovations, vol. 18. pp. S6-1-S65, 2014, doi: 10.1179/1432891714Z.000000000921.

[132] S. M. Islam, R. Hashim, A. B. M. S. Islam, and R. Kurnia, “Effect of peat on physicomechanical properties of cemented brick," The Scientific World Journal, vol. 2014. 2014, doi: 10.1155/2014/328516.

[133] A. A. Mahmood, M. K. Hussain, and S. N. Ali Mohamad, “Use of palm oil fuel ash (POFA)-stabilized Sarawak peat composite for road subbase," Materials Today: Proceedings, vol. 20. pp. 505-511, 2020, doi: 10.1016/j.matpr.2019.09.178.

[134] N. H. Md Zain and M. I. Zulastry, "Compressive Strength of Peat Soil Treated with Waste Tyre Granules," in Lecture Notes in Civil Engineering, vol. 59, Springer, 2020, pp. 185-192.

[135] V. Lapkovskis, V. Mironovs, K. Irtiseva, and D. Goljandin, "Study of devulcanised crumb rubber-peat bio-based composite 
for environmental applications," Key Eng. Mater., vol. 799 KEM, no. February, pp. 148-152, 2019, doi: 10.4028/www.scientific.net/KEM.799.148.

[136] K. Irtiseva et al., "Towards Next-Generation Sustainable Composites Made of Recycled Rubber, Cenospheres, and Biobinder," Polymers (Basel)., vol. 13, no. 4, p. 574, Feb. 2021, doi: 10.3390/polym13040574.

[137] J. Liiv, T. Teppand, E. Rikmann, and T. Tenno, “Novel ecosustainable peat and oil shale ash-based 3D-printable composite material," Sustain. Mater. Technol., vol. 17, p. e00067, 2018, doi: 10.1016/j.susmat.2018.e00067.

[138] A. Khoshand and M. Fall, "Geotechnical characterization of peat-based landfill cover materials," J. Rock Mech. Geotech. Eng., vol. 8, no. 5, pp. 596-604, 2016, doi: 10.1016/j.jrmge.2016.05.007.

[139] L. Voropai et al., "The Influence of the Relative Content of Peat and Mineral Binder on Thermal Insulation Composite Performance Characteristics," Int. J. Technol., vol. 11, no. 8, pp. 1618-1627, 2020, doi: 10.14716/ijtech.v11i8.4542.

[140] M. V. Efanov, V. V. Kon'shin, and A. A. Sinitsyn, "Production of Composite Materials from Peat and Wood by Explosive Autohydrolysis," Russ. J. Appl. Chem., vol. 92, no. 1, pp. 45-49, 2019, doi: 10.1134/S1070427219010063.

[141] I. H. M. Idris and N. Z. Yusof, "Development of low thermal mass cement-sand block utilizing peat soil and effective microorganism," Case Stud. Constr. Mater., vol. 8, pp. 8-15, 2018, doi: 10.1016/j.cscm.2017.11.004.

[142] P. Nechita, "Use of Recycled Cellulose Fibers to Obtain Sustainable Products for Bioeconomy Applications," in Generation, Development and Modifications of Natural Fibers, 2020.

[143] J. Treinyte, V. Grazuleviciene, D. Bridziuviene, and J. Svediene, "Properties and behaviour of starch and rapeseed cake based composites in horticultural applications," Est. J. Ecol., vol. 63, no. 1, pp. 15-27, 2014, doi: 10.3176/eco.2014.1.02.

[144] R. Stapulioniene, S. Vaitkus, and A. Kremensas, “THERMAL CONDUCTIVITY INVESTIGATION OF COMPOSITE FROM HEMP AND PEAT FIBRES," Environ. Eng. Manag. J., vol. 14, no. 9, pp. 2213-2220, 2015, doi: 10.30638/eemj.2015.235.

[145] V. Grazuleviciene, L. Augulis, J. V. Grazulevicius, P. Kapitanovas, and J. Vedegyte, “Biodegradable starch, PVA, and peat composites for agricultural use," Russian Journal of Applied Chemistry, vol. 80, no. 11. pp. 1928-1930, 2007, doi: 10.1134/S1070427207110304.

[146] G. Mckay, "Peat for Environmental Applications: A Review,” Dev. Chem. Eng. Miner. Process., vol. 4, no. 3-4, pp. 127-155, Sep. 1996, doi: 10.1002/apj.5500040302.

[147] “No Title." .

[148] J. de D. K. Hakizimana and H.-T. Kim, "Peat briquette as an alternative to cooking fuel: A techno-economic viability assessment in Rwanda," Energy, vol. 102, pp. 453-464, May 2016, doi: 10.1016/j.energy.2016.02.073.

[149] M. Adib, Z. Al-Qodah, and C. W. Z. Ngah, “Agricultural bio-waste materials as potential sustainable precursors used for activated carbon production : A review," Renew. Sustain. Energy Rev., vol. 46, pp. 218-235, 2015, doi: 10.1016/j.rser.2015.02.051.

[150] C. Cojocaru, M. Macoveanu, and I. Cretescu, "Peat-based sorbents for the removal of oil spills from water surface: Application of artificial neural network modeling," Colloids Surfaces A Physicochem. Eng. Asp., vol. 384, no. 1-3, pp. 675-684, Jul. 2011, doi: 10.1016/j.colsurfa.2011.05.036. 